\title{
Big Push or Big Grab? Railways, Government Activism and Export Growth in Latin America, 1865-1913 ${ }^{1}$
}

\section{By VINCENT BIGNON, RUI ESTEVES and ALFONSO HERRANZ-LONCÁN}

\begin{abstract}
Railways were one of the main engines of the Latin American trade boom before 1914. Railway construction often required financial support from local governments, which depended on their fiscal capacity. But since the main government revenues were trade-related, this generated a two-way feedback between government revenues and railways, with a potential for multiple equilibria. The empirical tests in this paper support the hypothesis of such a positive two-way relationship. The main implication of our analysis is that the build-up of state capacity was a necessary condition for railway expansion and also, to a large extent, for export expansion in Latin America during the first globalisation.
\end{abstract}

One of the main challenges faced by developing countries derives from the need to secure an adequate level of infrastructure. ${ }^{2}$ While large infrastructure investment may be insufficient to stimulate an economy if other fundamental growth determinants are lacking, income growth can be substantially depressed by inadequate or insufficient infrastructure. Such was indeed the case in Latin America during the first globalisation period. In the export-led growth process that preceded the First World War, the ability of most Latin American economies to take advantage of the opportunities opened up by the integration in world markets largely depended on the availability of transportation facilities to channel commodities to the international economy.

Within those countries' transport systems, railways played a prominent role, as the cheapest available means for the inland conveyance of freight. Due to the shortage of

\footnotetext{
${ }^{1}$ We are grateful to Andrés Álvarez, Leticia Arroyo-Abad, Andrea Bassanini, Dan Bogart, Theresa Gutberlet, Silvana Harriet, Nuno Palma, José A. Peres-Cajías, Florian Ploeckl, María Teresa Ramírez, Jaime Reis, Fabbio Sanches, Richard Sicotte, Bill Summerhill, and participants at the ALL-UC Group Conference on Transport, Institutions, and Economic Performance: Historical Perspectives (UC-Irvine, December 2011), the XVI World Economic History Congress (Stellenbosch, July 2012), the seminar of the Colombian Economic History Association at Los Andes University in Bogotá (October 2012), the APHES conference in Lisbon (November 2012), the EHS conference in York (April 2013) and the World Business History Congress (Frankfurt, March 2014). We also thank Juan H. Flores and Béatrice Dedinger for sharing unpublished data with us. None of them are responsible for the mistakes of the text. The views expressed in this paper are not necessarily those of the Banque de France or the Eurosystem.

${ }^{2}$ See, e.g., Estache, 'Infrastructure and development'; Straub, 'Infrastructure and growth'.
} 
alternative infrastructure and the scarcity of navigable routes, in many countries railways became essential for the exploitation and export of a large share of the natural resources that constituted those economies' comparative advantage. Whereas railways could not generate economic development in the absence of other fundamental factors, their shortage could significantly constrain export expansion and income growth. This explains why some of the available estimates of the economic impact of railways in Latin America are very high in comparative terms. ${ }^{3}$

Despite its potentially high growth impact, railway investment did not spread evenly throughout the region. In many Latin American countries the development of rail transport was sluggish and the final network mileage was disappointingly low, which may have prevented those economies from taking full advantage of the opportunities opened by the first globalisation. There are several potential explanations for this failure to build dense railway networks in certain countries, such as ruggedness or institutional instability. But, as is usual with infrastructure investment in developing countries, ${ }^{4}$ differences in the intensity of railway construction among countries also seem to have depended on each government's financial capacity to subsidize construction or to guarantee a certain level of profits to private investors.

The dependence of Latin American railway expansion on government resources can be rationalized in the context of the 'big push' models, in which government intervention was required to overcome coordination failures and bring an economy from a low to a high-level equilibrium. ${ }^{5}$ However, it is also consistent with a 'big grab' explanation, in which government and investors' money was necessary not only to build railways with high positive externalities, but also to pay for greasing the wheels of politics, and/or to channel rents to railway promoters. And, finally, it could also stem from the redistributive effects of infrastructure, which could generate resistance and the need to compensate losers in exchange for their approval. ${ }^{6}$ These explanations may jointly help to understand why, despite their high potential social returns, the majority of the railways that were built in Latin America required government support.

\footnotetext{
3 Coatsworth, 'Indispensable railroads'; Summerhill, Order against progress; Herranz-Loncán, 'Transport technology'.

${ }^{4}$ Eichengreen, 'Financing infrastructure'.

${ }^{5}$ Rosenstein-Rodan, 'Problems of industrialisation'; Murphy et al., 'Industrialization and the big push'; Bjorvatn and Coniglio, 'Big push or big failures'.

${ }^{6}$ Redistribution of rents to ensure cooperation is actually a feature of politics in countries with limited access order; see North et al., Violence and social orders.
} 
The dependence of railway investment on government resources, however, posed a complex puzzle in a period in which most revenues of Latin American governments derived from trade taxes. Such fiscal structure implied that government resources were limited in each country by the degree of trade expansion. But this, in turn, as has been indicated, might have been hindered in some economies by an insufficient endowment of transportation infrastructure and the scarcity of railway routes. This could have created a double feedback relation wherein railway construction was limited by the size of government revenues, and these could only grow with the expansion of foreign trade, but trade development was only possible through the enlargement of the railway network. This mutual causation relationship would be consistent with the existence of multiple equilibria and the possibility of some countries being caught in a nondevelopment trap of low foreign trade and low railway construction.

The objective of this paper is to test the existence of such bidirectional causality between government revenues and railway development. To that end we estimate a two equation model of government revenues and railway expansion in Latin America between 1865 and 1913 and find supportive evidence of a positive two-way relationship between the two variables, which is robust to several specifications.

We do not explore here the specific reasons (such as geography, institutions, or bad luck in the 'commodity lottery', among others) that explain why some countries fell into a low development trap under those circumstances. Instead, in this paper, rather than exploring the particular ultimate factors that explain each country's evolution, we suggest some clues about one of the channels through which those factors affected the Latin American economies during the period. Our results indicate that countries with unfavourable circumstances not only found difficulties to export, but were also unable, due to the impossibility to increase their government revenues, to build the infrastructure that would have allowed them to remove their external constraints. In addition, over and above each country's initial (dis)advantages, our results also indicate that exogenous short-term shocks to state revenues had long-term effects on railway expansion and, therefore, on export growth. Our analysis may contribute in this way to a better understanding of the different ability of Latin American economies to reap the potential gains from globalisation before 1914. 
During the first globalisation, railways were a key factor for trade growth in Latin America. Due to the scarcity of alternative infrastructure and the limited reach of the available water routes in most of the region, domestic transport costs before the railways were too high to allow a sustained and rapid growth of exports, except in areas with good access to waterways or for commodities with very high value-to-weight ratios, such as gold or silver.

With a few exceptions, Latin American economies' interior areas had to rely on overland transport for trade. Only a few feasible navigable routes were available, such as the Amazonas in Brazil, the Magdalena in Colombia or the River Plate system in Uruguay and North-East Argentina, and even there conditions for navigation were not always favourable. ${ }^{7}$ In addition, Latin American pre-railway overland transportation was very precarious. Most roads were not accessible for carts, and a large share of freight transport depended exclusively on pack animals. ${ }^{8}$ The primitive character of Latin American road transport can be illustrated by the ratio between the average unit price of pre-railway (largely road) freight transport and the average rates of railway freight, which reached levels of 7 to 13 in Argentina, Brazil or Mexico in the early $20^{\text {th }}$ century. By comparison, a few decades earlier that ratio had ranged from 2.6 to 3.3 in England and Wales, France or the US. ${ }^{9}$

Under these circumstances, in many countries railways became essential for the exploitation of natural resources in inland areas, and crucial for export expansion to achieve its full growth potential. A preliminary illustration of the correlation between railway development and export growth is provided in Figure 1, which shows that those countries that reached higher levels of exports per capita in 1913 also invested more resources per capita in railways. This correlation is consistent with the fact that Latin American railways were mainly specialized in freight. By 1910-14, and in contrast with

\footnotetext{
${ }^{7}$ For instance, traffic through the Magdalena River was slow and highly dependent on weather conditions, and the route was only partially navigable; see Ramírez, 'Los ferrocarriles' or Safford, 'El problema de los transportes'.

${ }^{8}$ On pre-railway transport infrastructure in Spanish America see Gutiérrez Álvarez, Las comunicaciones, as well as Summerhill, Order against progress, for Brazil, Clark, 'Railway building', for Ecuador, Coatsworth, Growth against development, for México, or Zegarra, 'Transport costs and economic growth' for Peru. In some cases, such as Mexico, the transport system experienced an involution between the end of the colonial period and the 1870s, with a decrease in wheeled traffic and an increase in the use of pack animals; see Riguzzi, 'Los caminos del atraso'.

${ }^{9}$ Figures calculated from Herranz-Loncán, 'Transport technology'; Fishlow, American railroads; Hawke, Railways and economic growth; and Caron, 'France'. The comparison reported in the text is biased by the fact that figures for England and Wales, France or the US are calculated for the 1860s and 1870s, and railway transport unit costs tended to decrease over time. However, productivity gains in the western countries' railway systems between 1860 and 1914 were far too low to bring these ratios to levels similar to the Latin American ones by 1914 (see, e.g., Crafts et al., 'Total factor productivity growth').
} 
the situation in most industrialized economies, freight revenues were between 2 and 4 times as large as passenger revenues in Argentina, Brazil, Costa Rica, Mexico, Peru and Uruguay, ${ }^{10}$ and a large share of railway freight in those countries consisted of exports. ${ }^{11}$ More specifically, railways were indispensable for the growth of several export sectors, such as saltpetre in Chile, coffee in Brazil, sugar in Cuba, silver and tin in Bolivia, or coffee, bananas and animal skins in Costa Rica. ${ }^{12}$ Conversely, the lack of railways has been identified as one of the main reasons for the sluggish growth of Colombian coffee exports, or Peruvian exports in general. ${ }^{13}$

\section{Figure 1 here}

Despite the positive impact of rail transport on export growth, many countries failed to build an extensive railway system. The first railway line in the region was opened in Cuba in 1837, only 12 years after the inauguration of the first British steam-driven public railway, but Cuba would not be joined by any other Latin American economy before the 1850s. Only then did railway construction start in Argentina, Brazil, Chile, Colombia, Costa Rica, Mexico and Peru, gradually spreading thereafter to the rest of the region. By 1900, all Latin American countries had some railways in operation, but the length of the national networks was very uneven. Railway construction had been very intense in Argentina, Brazil and Mexico, which accounted for approximately 75 per cent of the whole Latin American mileage by the late 1880s. When measured in relative terms, investment in railway infrastructure had also been remarkable in Chile, Uruguay, Cuba and Costa Rica, both in per capita terms and in relation to the national surface area, as may be seen in Table 1. Other countries, by contrast, clearly lagged behind this group.

\section{Table 1 here}

Table 1 may be taken as preliminary evidence of the different role that railways performed in each Latin American economy before 1914. Whereas some countries

\footnotetext{
${ }^{10}$ See Coatsworth, Growth against development; Zegarra, 'Transportation costs and the social savings'; Summerhill, Order against progress; Quesada Monge, 'Ferrocarriles y crecimiento'; and HerranzLoncán, 'El impacto directo' and 'The role of railways'.

${ }^{11}$ See, e.g., Coatsworth, Growth against development; Zegarra, 'Transportation costs and the social savings'. However, in the case of Mexico Kuntz Ficker, 'Mercado interno' has also stressed the importance of domestic-oriented traffic within total railway freight.

12 Thomson and Angerstein, Historia del ferrocarril; Summerhill, Order against progress; Zanetti Lecuona and García Álvarez, Caminos para el azúcar; Mitre, Los patriarcas and Bajo un cielo de estaño; Quesada Monge, 'Ferrocarriles y crecimiento'.

${ }^{13}$ Ocampo, 'El sector externo'; Zegarra, 'Transport costs and economic growth'.
} 
could benefit from relatively dense networks, in other cases the expansion of the new infrastructure was extremely slow and, by 1914, railway systems consisted just of a few isolated lines that connected particular production areas with the main ports, while hardly affecting large swathes of the territory. The social savings literature has confirmed that those Latin American countries that built extensive railway networks before 1914 obtained huge direct benefits from railway transport. Among those economies, social savings were only low in Uruguay, a country with some exceptional natural transport advantages which made railways less indispensable. ${ }^{14}$ In Argentina, Mexico and Brazil, where cheap transportation alternatives were not as abundant, railways provided social savings amounting on average to ca. one quarter of GDP by 1910-13. By contrast, in Peru and Colombia, two countries in which railway development remained disappointingly slow, the estimates of the social savings of railway freight for 1918 and 1927, respectively, range from 2 to 8 per cent of GDP. ${ }^{15}$

Given the high potential economic impact of railways in Latin America, analysing why railway development differed markedly across countries before 1914 may contribute to a better understanding of the reasons for the region's internal divergence. This requires an examination of the railway investors' decision making process. In Latin America, railway capital and entrepreneurial initiative came from three different origins: governments, domestic capitalists and foreign firms. The first two sources were relatively important at the beginning of the period, but gradually lost prominence. Already by 1899 governments owned just 16 per cent, and domestic capital 13 per cent of the total Latin American railway mileage, and those percentages had decreased even further by $1913 .^{16}$

\footnotetext{
${ }^{14}$ Herranz-Loncán, 'The role of railways'.

15 For Argentina, Herranz-Loncán, 'El impacto directo'; for Mexico, Coatsworth, 'Indispensable railroads'; for Brazil, Summerhill, Order against progress; for Colombia, Ramírez, 'Los ferrocarriles'; and, for Peru, Zegarra, 'Transportation costs and the social savings'.

${ }^{16}$ Public capital was especially important in some Central American economies and in Chile, although its presence was also noticeable in Colombia, Brazil and Argentina. In some economies (especially in Central America), state railways were largely financed by issuing external sovereign debt, which was used as a substitute for the lacking foreign direct investment. By contrast, in Argentina and Chile public investment was, to some extent, complementary to private undertakings, often financing lines that ran through poor and distant regions, as an instrument of political integration with very low profitability prospects. Domestic private capital was especially prevalent in Cuba (where it owned $40 \%$ of the network in 1899, but had controlled almost $100 \%$ until the 1880s), Puerto Rico, Brazil and Venezuela (with percentages of 20 to 30\% in 1899), and also, to a certain extent, in Chile, and was highly connected with certain export activities, such as Cuban sugar, Brazilian coffee, or Chilean copper mining (Sanz Fernández, Historia de los ferrocarriles; on the role of domestic capital see also Lewis, 'The financing of railway development', pp. 257-60).
} 
By far, the largest share of Latin American railway capital came from foreign investment, which entered the region mainly in the form of new construction initiatives, but also by taking over publicly-owned and domestic private firms. ${ }^{17}$ The relevance of foreign capital increased since the 1880s, especially after the Baring crisis led to the failure of several local initiatives, and foreign enterprises ended up controlling almost 75 per cent of the railway mileage in 1899, and an even higher percentage (80 to 90 per cent) in the years immediately before 1914. Among foreign investors, capital raised in London was absolutely dominant during the late nineteenth century, accounting for 70 per cent of the mileage under foreign operation in 1899. However, since 1900 the importance of US capital grew rapidly, being especially relevant in the US area of influence i.e. Mexico, the Caribbean and Central America. ${ }^{18}$

Since the majority of Latin American railway investment was financed by foreign capital, those factors that made some destinations more attractive than others to foreign investors may account for cross-country differences in railway development. Beyond each country’s geographical characteristics (e.g. ruggedness), Latin American railway historians have associated foreign investment and railway construction dynamism with three main factors: i) the degree of institutional stability; ii) governments' financial capacity to subsidize the railway system; and iii) the growth of exports of one or several products of increasing world demand. ${ }^{19}$ The first of these three factors may explain why, in most countries, significant construction only started in the late 1860s or early 1870s, once post-independence political turmoil had sufficiently abated. The two exceptions were Cuba and Chile, which were among the most institutionally stable countries after independence. Cuba, which remained linked to the Spanish Empire until 1898, was one of the first countries in the world to build railways, and in Chile construction was very active since the early 1850 s.

Government involvement was also crucial for railway development to take off, either through subsidies to private investment and different types of public-private partnership, or through direct public construction. Railway subsidies took different forms, such as interest guarantees (often at 7 per cent of invested capital), or a fixed construction subsidy per mile (as in Mexico and Honduras, for instance), and constituted a large

\footnotetext{
${ }^{17}$ Privatization of public lines was very important in some countries, such as Peru, where foreign capital bought a large percentage of public railways in 1890, and Argentina and Mexico in the closing years of the 19th century.

${ }^{18}$ Sanz Fernández, Historia de los ferrocarriles.

${ }^{19}$ See ibid., in the different country studies included in the book.
} 
burden on many Latin American budgets. ${ }^{20}$ Examples of the direct link between well funded public support and the start of railway construction are abundant. In Chile, for instance, the completion of the Santiago-Valparaíso line in the 1850s was only achieved after the government entered the shareholder capital. ${ }^{21}$ Similarly, no construction took place in Brazil until the government started supporting it in 1852 and, in Argentina and Uruguay, provincial or central governments' financial support was granted since the arrival of the first railways. ${ }^{22}$ The expansion of the Peruvian railway network between the 1850 s and the 1870 s was also allowed for by the abundance of fiscal revenues. ${ }^{23}$

In contrast, the lack of central governments' resources is one of the factors that explain the delay in railway construction in Mexico before the Porfiriato or in Colombia until the 1880s, whereas the elimination of subsidies in Venezuela in 1892 was behind the sudden interruption in railway construction in this country. ${ }^{24}$ The main exception to this dependence of railway construction on government resources was Cuba, where the early railways were built without government support, on the basis of the sugar boom. Construction of railways in Cuba, however, stagnated in the 1860s and only accelerated again after independence, when subsidies were granted to new lines. ${ }^{25}$ With this exception, railways constructed without government support were usually cheaply built lines, which often connected the short distance between a firm's plant (which sometimes owned the lines) and the main port or a trunk railway line (such as the early mining railways in Northern Chile).

The need for government intervention was not exclusive of the railways. Many large investment projects in Latin America during this period also required government involvement or some kind of public-private partnership. ${ }^{26}$ Government involvement in those cases varied from direct public construction and management (especially in roads and ports), or subcontracting the construction to a foreign firm (as in the Mexican case with Pearson), to granting the foreign firm a monopoly, usually in very generous

\footnotetext{
${ }^{20}$ For instance, in Argentina the guarantees amounted to more than 4.5 million pesos by 1890, whereas the total budget of the nation was 33.6 million pesos; see López, Historia de los ferrocarriles; and in Mexico railway subsidies were one of the main factors behind the fiscal crisis of 1884-85 (Riguzzi, 'Los caminos del atraso').

${ }^{21}$ Thomson and Angerstein, Historia del ferrocarril.

${ }^{22}$ Summerhill, Order against progress; Gómez, 'El incierto lugar’; Lewis, British railways.

${ }^{23}$ Zegarra, 'Transport costs and economic growth'.

${ }^{24}$ Riguzzi, 'Los caminos del atraso'; Safford, 'El problema de los transportes’; Sanz Fernández, Historia de los ferrocarriles.

${ }^{25}$ Zanetti Lecuona and García Álvarez, Caminos para el azúcar.

${ }^{26}$ British investment in Latin American public utilities (specially, urban transport) increased continuously since 1865, and reached very high levels (up to one third of total British investment flows in Latin American railways) by 1913 (Stone, 'British long-term investment', p. 323).
} 
conditions. ${ }^{27}$ Subsidising schemes, similar to those used in the railways, although not very frequent, could also be found in some undertakings. ${ }^{28}$

There are several potential explanations as to why government resources were so crucial for the expansion of railway infrastructure. The most obvious is the presence of market failures and the need of government intervention to coordinate private investment, in line with the 'Big Push' hypothesis. Given the high fixed costs, indivisible capital and the long time that had to pass until full potential traffic and profits were reached, investors required some guarantee of return, in order to compensate for the perceived uncertainty as to whether export activities would take off and make the railway investment profitable. ${ }^{29}$ This uncertainty could have several origins, such as the incomplete settlement and the open frontier of some countries, the volatility of the terms of trade, or the perceived risk of unrest, violence, political instability and sovereign default.

Moreover, in some economies, and especially in the smaller ones, the market power of railway promoters may have increased the need for government resources. According to Bulmer-Thomas:

In the smaller republics the resources at the disposal of foreign companies created an unequal relationship with the governments of the countries themselves, and many contracts were signed that -with the benefit of hindsight- look excessively generous to the foreign companies. This was also true in some of the larger countries, such as Peru, where the weak fiscal position gave the government little room to maneuver. ${ }^{30}$ Similarly, as stressed by Lewis for the case of São Paulo, the promoters’ position was reinforced by the authorities' 'need to preserve their financial credibility, which made them easy victims of less scrupulous railway promoters', as well as by their lack of experience and the absence of financial or technical criteria to assess concessions and subsidies, especially at the beginning of the period. ${ }^{31}$ Finally, corruption and the promoters' connections with local governments often helped to secure generous concessions and public subsidies. These problems were more serious in small countries,

\footnotetext{
${ }^{27}$ Connolly, El contratista de Don Porfirio; Bulmer-Thomas, The economic History.

${ }^{28}$ Stone, 'British long-term investment'.

${ }^{29}$ Summerhill, Order against progress; Lewis, British railways.

${ }^{30}$ Bulmer-Thomas, The economic History, pp. 106-7.

${ }^{31}$ Lewis, British railways, p. 11; see also Connolly, El contratista de Don Porfirio.
} 
where railway promoters acquired almost limitless power to decide on many aspects of the economy, as happened in the case of Costa Rica with Keith and his collaborators. ${ }^{32}$

Finally, the dependence of railway construction on government resources was also associated to its redistribution effects, which could affect the political decision to implement or not certain infrastructure projects. Railway construction involved significant changes in the price of the surrounding land and in the degree of integration of labour and goods markets, which redistributed income between regions and industries, and destroyed local rents through increased competition. Because those redistributive consequences could fuel resistance, railway development required political skills and resources to negotiate the agreement of all parties potentially affected by the route of each line. In other words, governments needed to buy off the approval of local elites to railway projects. Sometimes, this also required investing public money (through subsidies) in some unprofitable railways. For instance, in the case of the Brazilian state of São Paulo, Lewis suggests that

... it would be facile to argue that unprofitable railway building was simply a function of a weak state apparatus unable to arbitrate between the competing claims of different groups. Peculiar circumstances apart ..., paulistas recognised that only in the new coffee zone were railways likely to prove financially viable ... However, there were pressing reasons why the province aspired to a more extensive network and why landowners were anxious to socialise construction costs, shifting to the Treasury the burden of unprofitable construction. ${ }^{33}$

The lack of resources to compensate losers or pay for the assent of local elites provoked the failure of some projects, as in Colombia, where the plans of the government in 1871 to give priority to the Ferrocarril del Norte, which would favour the states of Cundinamarca, Bocayá and Santander at the expense of the West and the Caribbean, generated resentment and were one of the reasons of the civil war of $1876 .^{34}$

The use of railway construction for redistributive purposes, or the promoters' exercise of their market power (not to mention corruption) might well have been responsible for an excessive investment in lines with low profitability prospects. Nevertheless, these problems are intrinsic to government intervention in infrastructure investment, together with the construction of lines for political, military or

\footnotetext{
32 Quesada Monge, 'Ferrocarriles y crecimiento'.

${ }^{33}$ Lewis, 'Public policy', p. 19.

34 Safford, 'El problema de los transportes'; Bogart, 'Did the Glorious Revolution', describes a similar case of elites’ blocking of infrastructure construction in seventeenth and eighteenth century Britain.
} 
administrative reasons, and were widespread worldwide in railway construction in the late nineteenth and early twentieth centuries. ${ }^{35}$

As a consequence of the negative effects of government involvement, the aggregate social rates of return of Latin American railways were probably lower than in a counterfactual situation with perfect information and no distortions. However, given the high social benefits estimated for railways in certain countries, the negative effects of state intervention were most likely offset by its positive effects on the improvement in the transport system. In the case of Brazil, for instance, 'guaranteed dividend policy attracted investments in railways that the country had failed to obtain previously' and, in those investment, the social rates of return (ranging from 11 to 28 per cent per year) were far higher than the private ones. It is true that the private benefits in the most profitable Brazilian railways were higher than the market rates of return and that, with perfect information, the subsidy might have been avoided. However, the cost of this policy mistake seems to have been small (compared with the social benefits provided by those railways) and, given the underlying degree of uncertainty, there was no guarantee that capital would have been forthcoming to those profitable undertakings in the absence of subsidies. $^{36}$

Together with institutional stability and government support, the third explanatory factor for differences in railway development among Latin American countries was export growth. External trade dynamism, however, was not only important as an indicator of potential profits for foreign investors, but also the main source of government revenues. The lion share of government resources came either from the taxation of natural resource extraction or, more commonly, from custom tariffs. According to Bulmer-Thomas:

... governments throughout the region relied heavily on import tariffs to generate public revenue. ... Tax reform brought about the elimination of many taxes inherited from colonial times and a concentration on external trade taxes; by the time of the First World War no country received less than 50 percent of public revenue from custom duties, and in many cases the share was more than 70 percent. ${ }^{37}$

\footnotetext{
${ }^{35}$ See, e.g., Millward, 'European governments'.

36 Summerhill, 'Market intervention', p. 564.

37 Bulmer-Thomas, The economic History, p. 110. See also Centeno, 'Blood and debt'; Coatsworth and Williamson, 'Always protectionist?'; and Rubio Varas, 'Protectionist but globalised?'. An extreme case of concentration was Chile, were customs accounted for more than $90 \%$ of public revenues in 1913 . By contrast, Paraguay represented an exception to the dependence on foreign trade taxes, due to its limited participation in world trade.
} 
As a consequence, export crises had deep negative consequences on railway investment, not just because they threatened the profitability of rail transport but also because they endangered the ability of governments to continue supporting railway construction.

For instance, in Ecuador, the Guayaquil-Quito railway (the main line of the system) could only be built after 1895, thanks not only to General Eloy Alfaro’s political will but, specially, to rising custom revenues from cocoa exports. ${ }^{38}$ In Peru, the slowdown of railway construction since the 1880s coincided with the loss of some guano deposits to Chile in the War of the Pacific, and from the exhaustion of those that remained in Peruvian territory. Similarly, the expansion of the Peruvian railway system was only resumed in the two decades before 1914 thanks to the recovery of exports. ${ }^{39}$ In Mexico, the dismal export performance of the country before the Porfiriato is, together with the extreme regionalization of the structure of the Mexican state, one of the main reasons for the country's delay in railway construction. ${ }^{40}$ The same close association between exports, custom revenues and railway construction has been identified for other countries. $^{41}$

As mentioned previously, while railway expansion depended on government revenues and these, in turn, on foreign trade growth, the latter was also, to a large extent, a consequence of railway development. This mutual causation between, on the one hand, foreign trade and government revenues and, on the other, railways, had the potential to generate multiple equilibria. The objective of the next sections is to test the existence of such multiple equilibria by analysing the bidirectional causality between government revenues and railway development over the period.

In order to test the two-way relationship between railways and government resources in Latin America before 1914, we specify two equations in which railway development depends on government revenues and these, in turn, depend on foreign trade, which was to a large extent dependent on railway expansion. Given the mutual causation between railway development and government revenues that is involved in this specification, we

\footnotetext{
${ }^{38}$ Clark, 'Railway building'.

${ }^{39}$ Bulmer-Thomas, The economic History; Zegarra, 'Transport costs and economic growth'.

${ }^{40}$ Riguzzi, 'Los caminos del atraso'; Bulmer-Thomas, The economic history.

${ }^{41}$ See, for instance, for El Salvador, Burns, 'The modernization of underdevelopment'.
} 
need an identification strategy to analyse the connection among the main variables. The equation for government revenue is:

$$
G_{i t}=\alpha+\beta T_{i t}+\gamma Z_{i t}+\chi_{t}+\eta_{i}+\varepsilon_{i t}
$$

where $G$ is government revenue, $T$ is the volume of imports (the main source of public resources in the region at the time) and $Z$ is a vector of covariates. We instrument for trade by using both railways and, as is customary in trade studies, the standard gravity controls, i.e. the product of the population of each country by the population of its main trading partners, and the effective distance between them. Railways are an appropriate instrument because, as has been indicated, they were a key factor for export (and therefore import) expansion. ${ }^{42}$ At the same time, they were not a direct source of public revenue, since taxes paid by private railway companies were negligible and the direct contribution of state-owned lines to total revenues was very small or null. In other words, the instrument verifies the exclusion restriction.

In vector $Z$ we include population as control for each economy's size, and several indicators of political instability (number of changes in the executive and the presence of interstate wars or other wars) that might have disturbed the collection of government revenue in a given year. ${ }^{43}$

The second equation is based on a rational expectations model of partial adjustment of investment in Latin American railways. This assumes that there was an ideal size for each country's railway network conditional on the available information on a number of relevant variables. More specifically,

$$
R_{i t}^{*}=a+b G_{i t}+c X_{i t}+n_{i}+d_{t}+e_{i t}
$$

\footnotetext{
${ }^{42}$ Although the argument of this paper relates railway construction to export growth, we use imports rather than exports in this equation because the majority of tariff revenue was raised on imports. Moreover, there is a tight empirical relation between the two sides of the trade account in this period. A simple AR model of deviations of the current account from equilibrium has a very small persistence, with a half-life of shocks of only 0.9 years. This can easily be reasoned. On the one hand, government revenues could only be reliably raised from imports if exports grew enough to avoid large current account deficits; otherwise foreign investors would have seen the potential risks and leave the country (and the railway sector, in particular), affecting its import capacity. On the other, in the absence of autonomous monetary policies and central banks in the region, it is unlikely that export booms did not encourage import growth over a relatively short period, since these countries' ability to sustain large current account surpluses and accumulate reserves was limited.

${ }^{43}$ Other wars include civil wars as well as colonial conflicts in Cuba or Puerto Rico during the period of Spanish rule. We also included an indicator for border changes to control for exogenous variations in countries' scale, which takes the value of one for Chile, Bolivia and Peru in 1883 (Pacific war) and for Colombia in 1904, to account for the loss of Panama.
} 
where $R^{*}$ is a latent variable representing the desired length of railways, $G$ is government revenue and $X$ a vector of covariates. Moreover, we model a partial adjustment mechanism, whereby investors (public or private) caught up each year with the desired network size. In other words, the growth rate of the railway network would be a fraction of the gap between its ideal level and the size of the inherited network:

$$
\mathrm{R}_{\mathrm{it}}-\mathrm{R}_{\mathrm{i}, \mathrm{t}-1}=\delta\left(\mathrm{R}_{\mathrm{i}, \mathrm{t}-1}^{*}-\mathrm{R}_{\mathrm{i}, \mathrm{t}-1}\right)
$$

Replacing (3) in (2), we obtain the equation to estimate:

$$
R_{i t}-R_{i, t-1}=\delta a-\delta R_{i, t-1}+\delta b G_{i, t-1}+\delta c X_{i, t-1}+\delta n_{i}+\delta d_{t-1}+\delta e_{i t-1}
$$

Since we are interested in the long-run coefficients of equation (2) (i.e. the relationships between the covariates and the desired network density level), we recover them as $b=$ $(\delta b) / \delta$, and $c=(\delta c) / \delta$.

To account for its potential endogeneity, we instrument for government revenue in this equation with two variables: each country's total level of diplomatic representation abroad, as compiled by Bayer, and an index of legislative effectiveness of each government, taken from Banks' database. ${ }^{44}$ For the exclusion restriction to hold, these variables must be good predictors of government revenue but not of railroad mileage growth, at least directly. 'Legislative effectiveness' was coded by Banks as an index of parliaments' autonomy and power, particularly of their 'authority with regard to taxation and disbursement'. ${ }^{45}$ The reason to use this instrument is that more effective legislatures would be better at raising government revenue inasmuch as they created the vehicle for a more consensual fiscal deal in society than, say, a confiscatory dictatorship. Arguably, more effective legislatures could also promote railway expansion faster than a dictatorship, but the evidence in Latin America offers some clear

\footnotetext{
${ }^{44}$ Bayer, 'Diplomatic exchange data set'; Banks, 'Cross-national'.

${ }^{45}$ In Banks' database, 'Legislative effectiveness' is coded zero if no legislature exists, ' 1 ' if legislative activity is of a 'rubber stamp' character, domestic turmoil makes its implementation impossible or the executive impedes the exercise of its function, ' 2 ' if the executive's power substantially outweighs, but does not completely dominate, that of the legislature, and ' 3 ' for an effective legislature distinguished by significant autonomy, including substantial authority with regard to taxation and disbursement and the power to override vetoes by the executive. This variable has been used, for instance, to estimate indices of state expansion (Schofer and Longhofer, 'The structural sources'), and as a measure of institutional development (Campos and Nugent, 'Who is afraid').
} 
counter-examples, such as the railway boom after Porfirio Díaz’s takeover in Mexico, or the railway expansion in Venezuela under General Antonio Guzmán Blanco (1870-88). In other words, railway investors and promoters could sometimes be agnostic about the nature of local political institutions, provided they were stable and predictable.

In the case of diplomatic representation, we posit that countries could only afford more (or more expensive) diplomatic representations if they had a higher and more stable level of revenues. This explains the correlation between both variables, which is enough to meet the exclusion restriction. On the other hand, the evolution of diplomatic representation would only very indirectly affect the rhythm of railway construction. To be sure, foreign representations could be opened abroad in order to publicize investment opportunities in the country, and so might be correlated with the error term of equation (4). However, by 1865 all Latin American countries in the sample already had some form of diplomatic representation in the UK, France, Germany or the US, which were the almost exclusive sources of foreign investment in railroad construction in Latin America. ${ }^{46}$ Likewise, diplomatic representations might be opened up abroad to promote trade with foreign countries and, since a large share of Latin American railway traffic was linked to foreign trade, the diplomatic instrument might then have a direct influence on the left-hand side variable. To take heed of this problem, we include in the vector of controls $X$ two standard gravity variables (the product of the population of each country and its main trading partners, and the effective distance among them), under the assumption that cheaper access to the core markets would have increased the latent demand for transportation in Latin America. But since these are exogenous gravity variables, we do not expect them to correlate with the total size of the diplomatic corps. $^{47}$

Regarding the other covariates in $X$, we consider a number of economic, political and financial variables that might have influenced railway development in each country. Among the economic variables, we include the evolution of the terms of trade, constructed by using international prices of the main articles of export of each country. As for the potential influence of political and institutional variables, we include again several indicators of political instability (number of changes in the executive, interstate

\footnotetext{
${ }^{46}$ Cuba and Puerto Rico were, of course, exceptions, but this was compensated by their belonging to the Spanish colonial empire up to 1898, and by the American protectorate thereafter, which provided a favourable access to the American financial markets.

47 So, if the diplomatic service was also driven by the same gravity forces, the instrument would be exogenous.
} 
and other wars), which might have been a deterrent to railway investment, both directly (i.e. through the lower friendliness of the business environment) and indirectly, because of the difficulty to reach consensus on taxes and therefore to increase government capacity to subsidize railway construction. ${ }^{48}$

We also take into account the potential for financial rationing in the international capital markets, particularly as a consequence of sovereign defaults. According to both historical and contemporary evidence, the corporate sector suffers a big penalty from sovereign defaults in rationed access to external finance. ${ }^{49}$ In addition, some defaults might have been related to the use of public money to subsidize unprofitable railways or unscrupulous foreign railway promoters, which would be a deterrent for additional investment. Having tried several proxies of access to foreign capital, such as sovereign spreads, we decided to use a simple measure of market memory of defaults, dependent on the number of years elapsed since the last default. ${ }^{50}$ We did so for two reasons: one, because this memory variable is a good predictor of spreads and, two, because we can compute it for the whole sample, whereas the availability of market yields for the debts of Latin American countries was more limited. ${ }^{51}$ As additional financial variable, we also include each country's exchange rate regime, since Latin American countries on silver or with paper currencies had to face persistent depreciation against the gold standard countries for most of the period. Since they imported the bulk of their railway inputs (rails and rolling stock) from gold countries this depreciation increased construction and running costs in domestic currency. Finally, we also include an index of global liquidity (the yield on British consols), as an approximation to variations in the international financial climate.

The summary statistics for the variables included in the two equations, as well as the instruments, for the estimated samples are listed in Table 2. Their sources are detailed in the data Appendix at the end of the paper. ${ }^{52}$

\footnotetext{
${ }^{48}$ We also include the same border changes marker of equation (1).

49 Bergquist, Coffee and conflict; Arteta and Hale, 'Sovereign debt crises'; Esteves and Jalles, 'Like fathers like sons?'.

${ }^{50}$ Actually, we use a non linear transformation of this variable because some countries never defaulted. Therefore, we computed the variable $y=x /(x+1)$, where $x$ is the number of years since the last default, and which increases with distance from last default and converges to 1 for countries that never defaulted.

${ }^{51}$ Moreover, for the sub-sample for which spreads are available the tenor of the results does not change when we substitute spreads for the non linear memory variable.

${ }^{52}$ We used the test of unit roots in panels proposed by Choi, 'Unit root tests', and could not reject the stationarity of all variables (including the instruments).
} 


\section{Table 2 here}

III

Table 3 shows the 2SLS estimates of equation (1), including the first-stage results. All the variables (bar the dummies) are converted to logs and to allay any further concerns about endogeneity we lagged all right-hand side variables by a year. ${ }^{53}$ As has been indicated, other than railway mileage, we included in the instruments list two gravity variables - mass (product of populations of each country and its trading partners in Europe and the US) and effective distance. Preliminary inspection suggested that the relation between trade and railways might be quadratic, so in order to improve power, we also included a quadratic term of railway length.

\section{Table 3 here}

Generally speaking, all significant variables have the expected signs, with a few exceptions. The instruments pass the tests of under-identification (Kleinberg-Paap and Anderson canonical correlation) and weakness (Cragg-Donald and Stock-Wright). However, apart from the last specification, there are problems with the test of overidentification (Sargan and Hansen J). ${ }^{54}$ There is some variation in the size of the coefficients of our variable of interest (the share of the variation of imports explained by railways and the gravity variables) when we introduce country fixed effects in the last two columns. It is probably safe to say that the elasticity of government revenues with respect to trade hovered between 0.3 and 0.4 . In the last column the population variable is highly significant, confirming the expected size effect on government revenues. Since the estimated elasticity is greater than one that would imply increasing returns to scale, which is a plausible case. However, the coefficient estimates for this variable are not stable across models and it is therefore unclear how much weight we should give to this

\footnotetext{
53 In particular, we lag railways as instruments for trade in order to take account of possible serial correlation in the error terms of the two equations, which might violate the exogeneity condition in equation (1). We tried several lags and the results did not change materially.

${ }^{54}$ The Hausman-Wu type tests also reject the consistency of the OLS estimates (see the 'Exogeneity $p$ value), though the evidence is less strong in the last two models. Nevertheless, we conservatively retain the IV estimates.
} 
result. ${ }^{55}$ Finally, the political marker is only significant in the regressions without country fixed effects, suggesting that Latin American countries systematically differed in their levels of political stability across the whole period, as this variable has no explanatory power of the within variation of government revenues. ${ }^{56}$

Table 4 shows the results of estimating equation (4) also by 2SLS. The instruments pass all tests and in all specifications. The coefficient of lagged railway mileage, which stands for the (symmetric of the) velocity of adjustment of railway construction, is always significant, negative and lower than 1 . This is consistent with the partial adjustment model presented in equation (3) and implies an adjustment speed of up to 10 per cent per year. The size of our coefficient of interest is not entirely stable but, apart from column (6), hovers close to but below 0.2. Bearing in mind that the structural parameter is estimated as the ratio between the coefficient of government revenues and the velocity of adjustment, the implied long-term elasticity of railways to revenue is always above one and possibly as high as three.

\section{Table 4 here}

Although often correctly signed, the coefficients of the controls are mostly remarkable for their lack of statistical significance, except when country and year fixed effects are included. In the later specification, distance to the UK has the expected negative sign, arguably working through trade, but the signs of the mass variable and of the distance to the US are counterintuitive. Further, being at war with other states adversely impacted railway construction. The insignificance of the 'off gold' variable may suggest that higher construction costs over the short run did not dissuade investors from committing funds to the development of railways in countries with sound economic and financial prospects.

Institutional variables are also rarely significant, but have the expected sign when they are. It is possible that political differences across Latin American nations were sufficiently stable throughout the sample such that they have no explanatory power of the within variation, but are significant in explaining it between countries. Finally higher world interest rates do not seem to have dampened the rhythm of railway

\footnotetext{
55 The negative and significant coefficient of the population variable in model (2) is puzzling. But it disappears with FE (country or year), meaning that it might be actually capturing the effect of less populated countries (e.g. Southern Cone) having more government revenues per capita.

56 On the other hand, the positive effect of wars in models 3 and 5 might reflect the efforts of governments to raise revenues during wars.
} 
construction in Latin America, possibly because the recessionary effects of world financial crises are already captured by government revenues. ${ }^{57}$

In conclusion, the evidence in Tables 3 and 4 supports the hypothesis under test, i.e. that government intervention was crucial in the construction of Latin American railways and that these were, in turn, a key element in both the integration of these nations in the flows of world trade and their subsequent fiscal development prior to 1913. Given that we estimated a double feedback system it is interesting to study its dynamic stability. With linear functional forms, the stability condition resumes to a comparison of the slopes of the two functions: government revenues as a function of railways and railways as a function of government revenues. Stability requires that the first slope be smaller than the second, which is the case in the regressions with country and country/year fixed effects. This is represented in Figure 2, where the two lines were drawn by using the estimated coefficients and the sample averages of all the right-hand side variables. An exogenous shock to revenues or to railways in a particular country would therefore build up and converge to permanently higher levels of railway density and government revenues.

\section{Figure 2 here}

IV

There are several alternatives to pursue in testing the robustness of the previous results. The first has to do with the specification of the railway investment model that underlies equation (4). This rational expectations model assumes that investment decisions adjusted seamlessly to the acquisition of new information for railway prospects. However, as is well known on the theoretical and empirical literature on investment functions, simple accelerator models similar to equation (4) often fail empirically because of not accounting for the option value of waiting. ${ }^{58}$ In the face of uncertainty, rational investors have an option to wait for more confirming information before investing, what generates excessive inertia of investment to new information in equations such as (4). To try and account for this we ran the same model with longer lags.

\footnotetext{
${ }^{57}$ The consol variable drops out from model (7) because of collinearity with the year fixed effects.

${ }^{58}$ Dixit, 'Investment and hysteresis'; Pindyck, 'Irreversibility'.
} 
The second category of robustness considerations relates to the estimation method. Here we consider three different alternatives. First, even though we are estimating a double-feedback relation between railways and government revenues we chose to estimate the two equations separately by 2SLS. This guarantees consistent estimates of the structural parameters, but we can try and improve efficiency by using system methods and jointly estimating the two equations through 3SLS. Secondly, as an alternative treatment of endogeneity, we applied dynamic panels (Arellano-Bond) methods. The main advantage of this technique is to provide a large number of instruments consistent with the rational expectations component of our partial adjustment model of railway construction, which might address the problem of our instruments for government expenditures not being strong enough. And, finally, as a third variation on the issue of estimation methodology, we ran cointegrated panel models, which were specifically developed to deal with the possibility of nonstationarity in large $\mathrm{N}$ and large $\mathrm{T}$ dynamic panels. ${ }^{59}$

The results of these robustness checks are compared in Table 5, that focuses specifically on the elasticity of government revenues in the railway equation (i.e. $b=\delta b /$ $\delta){ }^{60}$ The first three columns compare the elasticities considering different lags. When we increase the number of lags we indeed obtain better fits and, although the size of the elasticity of railways to government revenues falls by 10 per cent relative to Table 4 , the difference is not statistically significant. ${ }^{61}$ However, in the end, as the length of the waiting period for railway investments in Latin America is not observable, we prefer reporting the results with one year lags of Table 4 .

\section{Table 5 here}

The next three columns of the table list the same elasticity under alternative estimation techniques. In the case of the 3SLS and Arellano-Bond methods, the elasticity loses its significance and the overall quality of the adjustment is actually worse than in the single equation models. ${ }^{62}$ Since 3 SLS estimation requires more stringent assumptions to yield consistent estimators than 2SLS, and the properties of the Arellano-Bond method

\footnotetext{
${ }^{59}$ Pesaran and Smith, 'Estimating long-run relationships'; Pesaran, Shin and Smith, 'Estimating long-run relationships' and 'Pool mean group estimation'.

${ }^{60}$ Full results are available from the authors on request.

${ }^{61}$ On the other hand, with lags up to three years more control variables become significant.

${ }^{62}$ The 3SLS model actually had a negative $\mathrm{R}^{2}$ and the Arellano-Bond regressions fail to pass the overidentification test.
} 
depend on having large cross-sections relative to the time dimension, which is not the case of our sample, all in all we prefer our original 2SLS results. ${ }^{63}$

In the case of the dynamic panel estimation, we preliminarily tested for panel cointegration using the four tests proposed by Westerlund. ${ }^{64}$ Even though we could not reject the absence of cointegration between our variables, we are aware of the low power of these tests with relatively short time dimensions for each individual cross section unit. Consequently, we still estimated our model as a cointegrated panel. In choosing the lag lengths we had to trade off quality of fit and degrees of freedom. As a compromise, we set a maximum lag of two years and used the individual lags that minimized the usual information criteria for model selection (AIC and BIC). In the last column of Table 5 we report the coefficient of government revenues in the pooled mean group specification (PMG), in which we allow the short-run coefficients to vary between countries, whereas imposing the same long-run coefficients. The elasticity estimate is significant, although lower than in Table 4, whilst the tenor of the results for the rest of the model is unchanged.

Our final robustness check also deals with the stability of the results through time, as it is possible that the results are weaker in the whole sample than in sub-periods. The 50-odd years covered by the regressions witnessed substantial transformations in terms of trade patterns and specialisation, state capacity and financial market integration, which could change the strength of the empirical relation under study. Focusing again on the railway equation (4), Figure 3 shows the coefficients of government revenues that result from dropping from the estimation the last years of the sample, starting from 1880 onwards.

\section{Figure 3 here}

This figure reveals an interesting pattern, although it has the problem that the estimates for the smaller samples are very imprecise, due to the drop of the majority of the observations. ${ }^{65}$ In any case, Figure 3 implies that there was a clear breakpoint between 1890 and 1893. In between these two years the coefficient of government revenues increases in size and becomes statistically significant. Arguably, this is an expression of

\footnotetext{
${ }^{63}$ Wooldridge, Econometric analysis.

${ }^{64}$ Westerlund, 'Testing for error correction'.

${ }^{65}$ For instance, by dropping all years from 1880 on we only retain 96 observations of the original sample of 480 .
} 
the fallout from the Baring crisis, which reduced the ability of Latin American countries to borrow from abroad. Under more stringent credit constraints, the collateral of government revenues became binding for railway construction. By contrast, during periods of credit expansion and railway investment booms, it was easy for governments to borrow, even without revenues that would justify it. In fact, the size of the coefficient was lower just before 1890 and had been falling throughout the 1880s. Similarly, after rising to a maximum of 0.55 in 1890, the elasticity of railway construction to government revenues fell systematically until 1910 (except for a hiccup in 1907, no doubt associated with the US stock market crisis) before rising again until the eve of the First World War. By the early teens the coefficient had fallen to close to 0.13. Despite this decrease, the coefficient remains significant after 1893, as shown in the second panel of Figure 3. Hence, our results, although influenced by the cyclical nature of world investment booms and busts, are not entirely driven by them.

Our estimation results indicate the presence of a double feedback relation between railway construction and government capacity in pre-war Latin America intermediated through foreign trade. Such relation is consistent with a multiple equilibria model and with the possibility for some Latin American countries to become stuck in a nondevelopment trap, in which foreign trade and government revenues did not grow enough due to insufficient railway development, and simultaneously railway development was stunted because of the low level of external trade and the consequent scarcity of state resources.

The requirement of government resources for the economies to reap the benefits of the railway technology would be consistent with both a 'big push' interpretation, in which the government would be functional in solving coordination failures, and a 'big grab' history, in which state revenues were necessary to grease the wheels of politics and negotiate with railway promoters and those local elites that could potentially block the projects. Under either of these assumptions, these results contribute to our understanding of the growing differences that opened up across Latin American economies during the first globalisation period. For instance, the prolonged stagnation of railway construction in Colombia, which originated in the difficulties that this country faced to increase exports and government revenues, contrasts with the sustained 
expansion of the rail systems of Argentina, Uruguay, or Mexico since 1879, closely associated with their growing involvement in world trade.

Our results also highlight the importance of short-term shocks in the long-term evolution of each economy. The impact of wars, sudden changes in the terms of trade or institutional changes affecting the ability of the government to collect resources also had a bearing on the future expansion of the railway system and the economy. In order to quantify the economic significance of these effects, Table 6 presents four counterfactual exercises whereby we investigate the required increase in government revenues for a given country to attain the same railway density (measured in $\mathrm{km}$ per $\mathrm{km}^{2}$ ) as another country with a more developed network by 1913. For instance, in the first row we consider the possibility of Colombia reaching the same railway density as Argentina in 1913 (11.5 km per 1,000 $\mathrm{km}^{2}$, rather than the actual 0.94). The push variable in these counterfactuals is the size of government revenues, which we introduced in a dynamic simulation of the size of the network by using the system of equations (1) and (4), while assuming that all other variables were kept at their historical levels. We consider two alternative scenarios: one where we add a permanent percentage increase to government revenues each year between 1865 and 1913; and the other where we shock revenues only once at the beginning of the period.

\section{Table 6 here}

The table shows that the required amounts to move each country to a different long-run path vary from modest to moderate. Focusing on the first line, the cumulated impact of a permanent 3 per cent annual increase in revenue since 1865 would have been required to bridge the gap between the densities of the Colombian and Argentinean networks. Alternatively, an initial injection of slightly less than 108 per cent of the Colombian revenue in 1865, representing just over $£ 1.5$ million, would have also achieved the same result. Very similar numbers would have been required for Colombia to match the slightly denser Uruguayan network. The last two cases in Table 6 involve countries of relatively similar size but ultimately different railway development. The figures for a Honduran convergence to the Costa Rican density in 1913 are much smaller than the Colombian ones, whereas the Peru-to-Mexico scenario would have demanded values in between these two cases. 
We report this exercise mostly for illustration and as a way of gauging the economic significance of the impact of government support to railway development in Latin America. Interpreted literally, these figures suggest that a modest capital injection would be sufficient to achieve higher levels of network density. However, the counterfactual estimates are conditional on the cœteris paribus assumption and we can imagine many reasons why a permanent increase in government revenue might be hard to sustain over 50 years. But any mitigating reasons do not ultimately detract from the importance of the public-private partnership link we establish in our analysis.

Finally, our estimates also allow identifying those cases in which countries received a (positive or negative) shock that altered the long term trend derived from their fundamentals. Figure 4 shows the rail mileage predicted by the model over time, according to the level of the underlying variables and the dynamics of the model, and compares it with the evolution of the actual railway length of each Latin American economy. ${ }^{66}$ Peru or Colombia are two clear cases in which an easily identifiable negative shock moved downward the predicted growth trend of the railway system, without any clear change in the 'ultimate' growth determinants of those countries.

\section{Figure 4 here}

The figure also shows the main deviations of the actual railway networks from their predicted level. Whereas in most countries both follow very similar trends, there are some interesting outliers. The most remarkable cases are, for different reasons, Chile and Colombia. Chile before the War of the Pacific (1879-83) is the main case of railway "overbuilding" in the region. Although our estimates predict the stagnation of the Chilean network at least until the end of the war, ${ }^{67}$ in fact the country expanded its network at good pace even before the war and the saltpetre export boom. To a large extent, this might partly be explained by the pioneering involvement of the Chilean government in the expansion of the railway network since the early 1850s. The opposite case is represented by Colombia (and also Ecuador or Honduras), where railway construction was much slower than predicted. In these countries, whereas the relatively

\footnotetext{
${ }^{66}$ Notice that all the predicted series coincide with the actual railway mileage in 1913 , because the dependent variable in equation (4) is the growth in railway mileage and the sum of error terms is zero in least squares estimators.

${ }^{67}$ Nothing prevents the predicted railway mileage from decreasing. However, since the closing down of lines was very rare during the period, we consider that a decrease in the predicted mileage would be consistent with stagnation in the actual length.
} 
low level of exports and government revenues did not allow for massive railway construction, the large divergence between the predicted and the actual mileage indicate that there were other additional obstacles to the expansion of the rail network. The Colombian case is the most striking, and the inability of this country to expand its railway system might have been associated to its particular difficulties to reach stable national consensus in the field of railway policy.

\section{VI}

This paper has analysed the interplay between government revenues, railway expansion and trade development in Latin America during the period of the first globalisation. Our results show that increasing government revenues triggered railway infrastructure development, which was instrumental in opening up the economies of Latin America to world oceanic trade. In turn, trade growth increased government revenues, which made the guarantees and subsidies to railways companies credible. We also found that the relationship between government revenues and railway expansion weakened during periods of easy international credit. A direct implication of our results is that, during the period under consideration, some countries might have been trapped in a low-level equilibrium, in which railways were not built because of insufficient government revenues, but these did not grow enough due to insufficient transport infrastructure and its negative effects on foreign trade. In that context, an exogenous positive shock to government revenues might have brought the economy from that low-level to a highlevel equilibrium.

Several explanations can account for the need of government resources to develop railway infrastructure, and we leave to future research the task to assess their relative importance. The main implication of our analysis is that the build-up of state capacity was a necessary condition for the extension of railways. Since the railways were clearly instrumental in export development and economic growth, our results may contribute to a better understanding of the growing divergence between the economies of the region during this period.

\section{APPENDIX: DATA SOURCES}

Railway data 
Yearly railway mileage has been taken from Mitchell, International historical statistics, and Sanz Fernández, Historia de los ferrocarriles, except in the following cases: Argentina (from Dirección de Ferrocarriles Nacionales, Estadística de los Ferrocarriles en Explotación, 1892-1913); Brazil (from www.ibge.gov.br); Chile (before 1870, own estimation from Marín Vicuña, Estudios, and Alliende Edwards, Historia del ferrocarril; from 1870 onwards, Braun et al., 'Economía chilena'; Cuba (from Zanetti Lecuona and García Álvarez, Caminos para el azúcar; México (from INEGI, Estadísticas Históricas); and Uruguay (own estimation from the country's statistical yearbooks).

\section{Population}

Population figures for Latin American countries have been taken from Yáñez, Rivero, Badia-Miró and Carreras-Marín, 'La población’; except for Puerto Rico, from Mitchell, International historical statistics, and Bolivia (own elaboration on the basis of Dalence, Bosquejo estadístico, and the country Population Censuses). Population of the main trade partners (UK and US) has been taken from Maddison, The world economy.

\section{Effective distance to the core markets}

We estimated effective distance following the procedure suggested by Clemens and Williamson, 'Wealth bias', i.e. we coded this variable as the product of a measure of geographic distance and an index of cost of shipping between each country and its main trade partners (UK and US). For most countries, geographical distance has been taken as the pre-Panama canal distance between the main port of each country and London or New York (or San Francisco in the case of the countries with the main port in the Pacific), as listed in Philip, Philip's mercantile maritime atlas, and National Imagery and Mapping Agency, Distances between ports. For the majority of nations we have used the index of tramp shipping freight charges from Isserlis, 'Tramp shipping cargoes', p. 122, with base year $1869=100$.

Imports, government revenues and exchange rates

Import data were kindly provided by Béatrice Dedinger. Some gaps in her data have been filled in with information taken from Mitchell, International historical statistics, the Correlates of War database, Schoonover, 'Central American commerce' and Puerto Rico official trade statistics. Total government revenue, in local currency units were obtained from Accominotti et al., 'The spread of empire', for the period 1880-1913. For the earlier period or countries not covered in this database, information was gathered from the following sources: Argentina from Cortés Conde, Dinero, deuda y crisis; Brazil from Motta et al., Estatísticas históricas, and several issues of the Brazilian budget laws; Chile from Wagner et al., 'Economía chilena', and Oficina Central de Estadística, Sinópsis; Colombia from Mitchell, International historical statistics, and Kalmanovitz, Nueva historia económica; Cuba from the official public budgets (various years), Mexico from El Colegio de Mexico, Estadísticas económicas; Wilkie, The Mexican revolution, and Mitchell, International historical statistics; Peru from Mitchell, International historical statistics and Tantaleán Arbulú, Política economicfinanciera; and Uruguay from Millot and Bertino, Historia económica (vol. II and III), and the Uruguayan Statistical Yearbooks. The majority of the exchange rate (local currency units per pound sterling) data comes from the compilation by Schneider et al., Währungen, or Accominotti et al., 'The spread of empire' with the following exceptions: Argentina from Cortés Conde, Dinero, deuda y crisis; Brazil from Motta et al., Estatísticas históricas; Colombia from Ocampo, Colombia, and the MOxLAD 
database at http://oxlad.qeh.ox.ac.uk/; Costa Rica from Soley Güell, Historia económica; Cuba from the MOxLAD database; Guatemala, Honduras and Nicaragua from Young, Central American currency; Peru from Ministerio de Fomento, Extracto estadítico.

Terms of trade

For those countries included in the database by Christopher Blattman et al., 'Winners and losers', and given that the UK was by far the main trading partner of Latin American countries throughout the period under analysis, we have used the ratio between a trade-weighted index of commodity export prices and an index of UK export prices, as compiled by Blattman et al., 'Winners and losers'. For other countries, we have computed the ratio between the price of the main export and an index of UK export prices. Each country's main exports are taken from Mitchell, International historical statistics, and the evolution of its price comes also from Blattman et al., 'Winners and losers'.

Defaults, spreads and exchange rate regimes

Default histories were coded from Esteves, 'Quis custodiet quem?', and Suter, Schuldenzyklen; the yields on British consols come from Accominotti et al., 'The spread of empire', and Homer and Sylla, A history of interest rates; spreads over British consols use mostly four sources: Accominotti et al., 'The spread of empire', Ferguson and Schularick, 'The empire effect'; Esteves, 'Quis custodiet quem?'; and Clemens and Williamson, 'Wealth bias'; exchange rate regimes (gold and silver/bimetallic standards) were coded from a number of sources: Accominotti et al., 'The spread of empire', Bae and Bailey, 'The Latin Monetary Union'; Esteves, 'Between imperialism and capitalism'; Ferguson and Schularick, 'The empire effect'; Leavens, Silver money; Meissner, 'A new world order'; Sédillot, All moneys; and Young, Central American currency.

Wars, changes in the executive, legislative effectiveness and diplomatic representation The numbers of international and other wars that affected each country were compiled from the Correlates of War database. The number of changes in the executive and the index of "legislative effectiveness" were taken from Banks, 'Cross-national'. Finally, the aggregate level of diplomatic representation was worked out from Bayer, Diplomatic exchange data set, that lists five levels of bilateral representation. We added up these indices for all the representations abroad of each Latin American country and used the sum as an instrument for government revenues.

\section{Footnote references}

Accominotti, O., Flandreau, M. and Rezzik, R., 'The spread of empire: Clio and the measurement of colonial borrowing costs', Economic History Review, 64 (2011), pp. 385-407.

Alliende Edwards, M. P., Historia del ferrocarril en Chile (Santiago, 1993).

Arteta, C. and Hale, G., 'Sovereign debt crises and credit to the private sector', Journal of International Economics, 74 (2008), pp. 53-69.

Bae, K.-H. and Bailey, W., 'The Latin Monetary Union: some evidence on europe's failed common currency’, Cornell University working paper (2003). 
Banks, A. S., 'Cross-national time-series data archive', Binghamton (NY), Center for Social Analysis (1994).

Bayer, R., 'Diplomatic exchange data set, v2006.1.' (2006): http://correlatesofwar.org

Bergquist, C. W., Coffee and conflict in Colombia, 1886-1910 (Durham, 1978).

Bértola, L. and Ocampo, J. A., Desarrollo, vaivenes y desigualdad. Una historia económica de América Latina desde la independencia (Madrid, 2010).

Bjorvatn, K. and Coniglio, N., 'Big push or big failures? On the effectiveness of industrialization policies for economic development', Journal of the Japanese and International Economies, 26 (2012), pp. 129-41.

Blattman, C., Hwang, J., Williamson, J. G., 'Winners and losers in the commodity lottery: The impact of terms of trade growth and volatility in the periphery 1870-1939', Journal of Development Economics, 82 (2007), pp. 156-79.

Bogart, D., 'Did the Glorious Revolution contribute to the transport revolution? Evidence from investment in roads and rivers', Economic History Review, 64 (2011), pp. 1073-112.

Braun, J., Braun, M., Briones, I. and Díaz, J., 'Economía chilena 1810-1995. Estadísticas históricas’, Santiago, Pontificia Universidad Católica de Chile, Documento de Trabajo 187 (2000).

Bulmer-Thomas, V., The economic history of Latin America since independence (Cambridge, 1994).

Burns, E. B., 'The modernization of underdevelopment: El Salvador, 1858-1931', Journal of Developing Areas, 18 (1984), pp. 293-316.

Campos, N. F. and Nugent, J. B., 'Who is afraid of political instability?', Journal of Development Economics, 67 (2002), pp. 157-72.

Caron, F., 'France”, in P. O'Brien, ed., Railways and the economic growth of western Europe (1983), pp. 28-48.

Centeno, M. Á., 'Blood and debt: war and taxation in nineteenth-century Latin America’, American Journal of Sociology, 102 (1997), pp. 1565-605.

Choi, I., 'Unit root tests for panel data', Journal of International Money and Finance, 20 (2001), pp. 249-72.

Clark, A. K., 'Railway building and nation building in Ecuador, 1895 to 1930' (Ph.D. Thesis, New School for Social Research, 1993).

Clemens, M. A. and Williamson, J. G., 'Wealth bias in the first global capital market boom, 1870-1913’, Economic Journal, 114 (2004), pp. 304-37.

Coatsworth, J. H., 'Indispensable railroads in a backward economy: the case of Mexico’, Journal of Economic History, 39 (1979), pp.: 939-60.

Coatsworth, J. H., Growth against development: the economic impact of railroads in porfirian Mexico (DeKalb, 1981).

Coatsworth, J. H. and Williamson, J. G., 'Always protectionist? Latin American tariffs from independence to Great Depression', Journal of Latin American Studies, 36 (2004), pp. 205-32. 
Connolly, P., El contratista de Don Porfirio. Obras públicas, deuda y desarrollo regional (Zamora, 1997).

Cortés Conde, R., Dinero, deuda y crisis. Evolución fiscal y monetaria en la Argentina 1862-1890 (Buenos Aires, 1989).

Crafts, N. F. R.; Mills, T. C.; and Mulatu, A., 'Total factor productivity growth on Britain's railways, 1852-1912: a reappraisal of the evidence', Explorations in Economic History, 44 (2007), pp. 608-34.

Dalence, J. M., Bosquejo estadístico de Bolivia (La Paz, 1975).

Dixit, A., 'Investment and hysteresis', Journal of Economic Perspectives, 6 (1992), pp. 107-32.

Eichengreen, B. R., 'Financing infrastructure in developing countries: lessons from the railway age', World Bank Research Observer, 10 (1995), pp. 75-91.

El Colegio de México, Estadísticas economicas del Porfiriato. Comercio exterior de Mexico 1877-1911 (Mexico, 1960).

Estache, A., 'Infrastructure and development: a survey of recent and upcoming issues', in F. Bourguignon and B. Pleskovic, eds., Rethinking infrastructure for development (Washington, 2007), pp. 47-82.

Esteves, R., 'Between imperialism and capitalism. European capital exports before 1914’, unpublished research paper (2007).

Esteves, R., 'Quis custodiet quem? Sovereign debt and bondholders' protection before 1914', University of Oxford, Department of Economics Working Paper no. 323 (2007).

Esteves, R. and Jalles, J., 'Like father like sons? The cost of sovereign defaults in reduced credit to the private sector', CEPR Discussion Paper no. 9303 (2013).

Ferguson, N. and Schularick, M., 'The empire effect: the determinants of country risk in the first age of globalization, 1880-1913', Journal of Economic History, 66 (2006), pp. 283-312.

Fishlow, A., American railroads and the transformation of the ante-bellum economy (Cambridge, MA, 1965).

Gómez, T., 'El incierto lugar de los ferrocarriles en las políticas públicas (1850-1950)', in B. M. Solveira, coord., Prescindencia e intervención. Relación retrospectiva entre Gobierno y Servicios Públicos (Córdoba, 2011), pp. 15-44.

Gutiérrez Álvarez, S.-J., Las comunicaciones en América: de la senda primitiva al ferrocarril (Madrid, 1993).

Hawke, G. R., Railways and economic growth in England and Wales (Oxford, 1970).

Herranz-Loncán, A., 'El impacto directo del ferrocarril sobre el crecimiento económico argentino durante la primera globalización', Revista Uruguaya de Historia Económica, 1 (2011), pp. 34-52.

Herranz-Loncán, A., 'The role of railways in export-led growth: the case of Uruguay, 1870-1913’, Economic History in Developing Regions, 26 (2011), pp. 1-32.

Herranz-Loncán, A., 'Transport technology and economic expansion: the growth contribution of railways in Latin America before 1914', Revista de Historia 
Económica-Journal of Iberian and Latin American Economic History, 32 (2014), pp. 13-45.

Homer, S. and Sylla, R., A history of interest rates (Hoboken, NJ, 2005).

INEGI, Estadisticas históricas de México (Mexico, 2009).

Isserlis, L., 'Tramp shipping cargoes, and freights', Journal of the Royal Statistical Society, 101 (1938), pp. 53-146.

Kalmanovitz, S., ed., Nueva historia económica de Colombia (Bogotá, 2010).

Kuntz Ficker, S., 'Mercado interno y vinculación con el exterior: el papel de los ferrocarriles en la economía del Porfiriato', Historia Mexicana, 45 (1995), pp. 39-66.

Leavens, D., Silver money (Blommington, IN, 1939).

Lewis, C. M. British railways in Argentina 1857-1914 (1983).

Lewis, C. M., 'The financing of railway development in Latin America, 1850-1914', Ibero-Amerikanisches Archiv, 9 (1983), pp. 255-78.

Lewis, C. M., 'Public policy and private initiative. Railway building in São Paulo', University of London, Institute of Latin American Studies, Research Paper no. 26 (1991).

López, M. J., Historia de los ferrocarriles nacionales 1866-1886 (Buenos Aires, 1994).

Maddison, A., The world economy. Historical statistics (Paris, 2003).

Marín Vicuña, S., Estudios de los ferrocarriles chilenos (Santiago, 1901).

Meissner, C., 'A new world order: explaining the international diffusion of the Gold Standard, 1870-1913', Journal of International Economics, 66 (2005), pp. 385406.

Millot, J. and Bertino, M., eds., Historia económica del Uruguay. Volumen II, 18601910 (Montevideo, 1996).

Millot, J. and Bertino, M., eds., Historia económica del Uruguay. Volumen III, 19101930 (Montevideo, 2005).

Millward, R., 'European governments and the infrastructure industries, c. 1840-1914', European Review of Economic History, 8 (2004), pp. 3-28.

Mitchell, B. R., International historical statistics: The Americas, 1750-2000 (Houndmills, 2003).

Mitre, A., Los patriarcas de la plata: estructura socioeconómica de la minería boliviana en el siglo XIX (Lima, 1981).

Mitre, A., Bajo un cielo de estaño: fulgor y ocaso del metal en Bolivia (La Paz, 1993).

Motta, R. da, Versiani, F. and Suzigan, W., eds., Estatísticas históricas do Brasil. Séries econômicas, demográficas e sociais de 1520 a 1988 (Rio de Janeiro, 1990).

Murphy, K. V., Shleifer, A. and Vishny, R. W., 'Industrialization and the big push', Journal of Political Economy, 97 (1989), pp. 1003-26.

North, D., Wallis, J.-J. and Weingast, B., Violence and social orders: a conceptual framework for interpreting recorded human history (Cambridge, 2009). 
Ocampo, J. A., Colombia y la economía mundial, 1830-1910 (Bogotá, 1984).

Ocampo, J. A., 'El sector externo de la economía colombiana en el siglo XIX', in A. Meisel Roca, A. and M. T. Ramírez, eds., Economía colombiana del siglo XIX (Bogotá, 2010), pp. 199-243.

Pesaran, M., Shin, Y. and Smith, R., 'Estimating long-run relationships in dynamic heterogeneous panels’ DAE Working Papers Amalgamated Series 9721 (1997).

Pesaran, M., Shin, Y. and Smith, R., 'Pooled mean group estimation of dynamic heterogeneous panels', Journal of the American Statistical Association, 94 (1999), pp. 621-34.

Pesaran, M. and Smith, R., 'Estimating long-run relationships from dynamic heterogeneous panels’, Journal of Econometrics, 68 (1995), pp. 79-113.

Philip, G., Philip's mercantile maritime atlas (1914).

Pindyck, R. S., 'Irreversibility, uncertainty, and investment', Journal of Economic Literature, 26 (1991), pp. 1110-48.

Quesada Monge, R., 'Ferrocarriles y crecimiento económico: el caso de la Costa Rica Railway Company, 1871-1905', Anuario de Estudios Centroamericanos, 9 (1983), pp. 87-119.

Ramírez, M. T., 'Los ferrocarriles y su impacto sobre la economía colombiana', Revista de Historia Económica, 19 (2001), pp. 81-122.

Riguzzi, P., 'Los caminos del atraso: tecnología, instituciones e inversión en los ferrocarriles mexicanos, 1850-1900', in S. Kuntz Ficker and P. Riguzzi, coord., Ferrocarriles y vida económica en México (1850-1950). Del surgimiento tardío al decaimiento precoz (Zinacantepec, 1996), pp. 31-97.

Rosenstein-Rodan, P. N., "Problems of industrialisation of eastern and south-eastern Europe”, Economic Journal, 53 (1943), pp. 202-11.

Rubio Varas, M. M., 'Protectionist but globalised? Latin American custom duties and trade during the pre-1914 belle époque', Universitat Pompeu Fabra, Working Paper 967 (2006).

Safford, F., "El problema de los transportes en Colombia en el siglo XIX”, in A. Meisel Roca and M. T. Ramírez, eds., Economía colombiana del siglo XIX (Bogotá, 2010), pp. 523-73.

Sanz Fernández, J., coord., Historia de los ferrocarriles de Iberoamérica (1837-1995) (Madrid, 1998).

Schneider, J., Schwarzer, O. and Denzel, M., Währungen der Welt (Stuttgart, 1911).

Schofer, E. and Longhofer, W., 'The structural sources of association', American Journal of Sociology, 117 (2011), pp. 539-85.

Schoonover, T., 'Central American commerce and maritime activity in the nineteenth century: sources for a quantitative approach', Latin American Research Review, 13 (1978), pp. 157-69.

Sédillot, F., All moneys of the world. A chronicle of currency values (New York, 1971).

Soley Güell, T., Historia económica y hacendaria de Costa Rica (San José, 1949). 
Stone, I., 'British long-term investment in Latin America, 1865-1913”, Business History Review, 42 (1968), pp. 311-39.

Straub, S., 'Infrastructure and growth in developing countries: recent advances and research challenges', World Bank, Policy Research Working Paper 4460 (2008).

Summerhill, W., 'Market intervention in a backward economy: railway subsidy in Brazil, 1854-1913’, Economic History Review, LI (1998), pp. 542-68.

Summerhill, W., Order against progress. Government, foreign investment, and railroads in Brazil, 1854-1913 (Stanford, 2003).

Suter, C., Schuldenzyklen in der Dritten Welt: Kreditaufnahme, Zahlungskrisen und Schuldenregelungen peripherer Länder im Weltsystem von 1820 bis 1986 (Frankfurt am Main, 1990).

Tantaleán Arbulú, J., Política económico-financiera y la formación del estado, siglo XIX (Lima, 1983).

Thomson, I.and Angerstein, D., Historia del ferrocarril en Chile (Santiago, 2000).

Wagner, G., Jofre, J. and Lüders, R., 'Economía chilena 1810-1995. Cuentas fiscales', Pontificia Universidad Catolica de Chile, Instituto de Economia: Documento de Trabajo no. 188 (2000).

Westerlund, J., 'Testing for error correction in panel data', Oxford Bulletin of Economics and Statistics, 69 (2007), pp. 709-48.

Wilkie, J., The Mexican revolution: federal expenditure and social change since 1910, (Berkeley, 1967).

Wooldridge, J., Econometric Analysis of Cross-Section and Panel Data (2002).

Yáñez, C., Rivero, R., Badia-Miró, M. and Carreras-Marín, A., 'La población de los países latinoamericanos desde el siglo XIX hasta el 2008. Ensayo de historia cuantitativa', DT-AEHE No 1202 (2012).

Young, J., Central American currency and finance (Princeton, 1925).

Zanetti Lecuona, Ó. and García Álvarez, A., Caminos para el azúcar (La Habana, 1987).

Zegarra, L. F., 'Transport costs and economic growth in a backward economy: the case of Peru, 1820-1920', Revista de Historia Económica-Journal of Iberian and Latin American Economic History, 29 (2011), pp. 361-92.

Zegarra, L. F., 'Transportation costs and the social savings of railroads in Latin America. The case of Peru”, Revista de Historia Económica-Journal of Iberian and Latin American Economic History, 31 (2013), pp. 41-72.

\section{Official publications}

Anuario estadístico de la República Oriental del Uruguay [1884-1913/14] (1888-1916).

Censo general de la población de la República de Bolivia según el empadronamiento de $1^{\circ}$ de septiembre de 1900 (1904).

Dirección de Ferrocarriles Nacionales, República Argentina, Estadística de los ferrocarriles en explotación [1892-1913] (1894-1916). 
Estadística general del comercio exterior de esta provincia de Puerto Rico (18621893).

National Imagery and Mapping Agency. Pub. 151. Distances between ports (2001).

Orçamento da receita e despeza da Republica dos Estados Unidos do Brazil [18921911] (1893-1911).

Orçamento do Imperio do Brazil. Orçamento da despexa e receita do Imperio [18651890] (1864-1889).

Perú. Ministerio de Fomento. Extracto Estadístico correspondiente al año 1918 (1918).

Presupuestos generals de gastos e ingresos de la isla de Cuba [1866-1893] (18661892).

República de Bolivia. Censo Demográfico de 1950 (1955).

Sinopsis Estadística de la República de Chile. Año 1918 (1919).

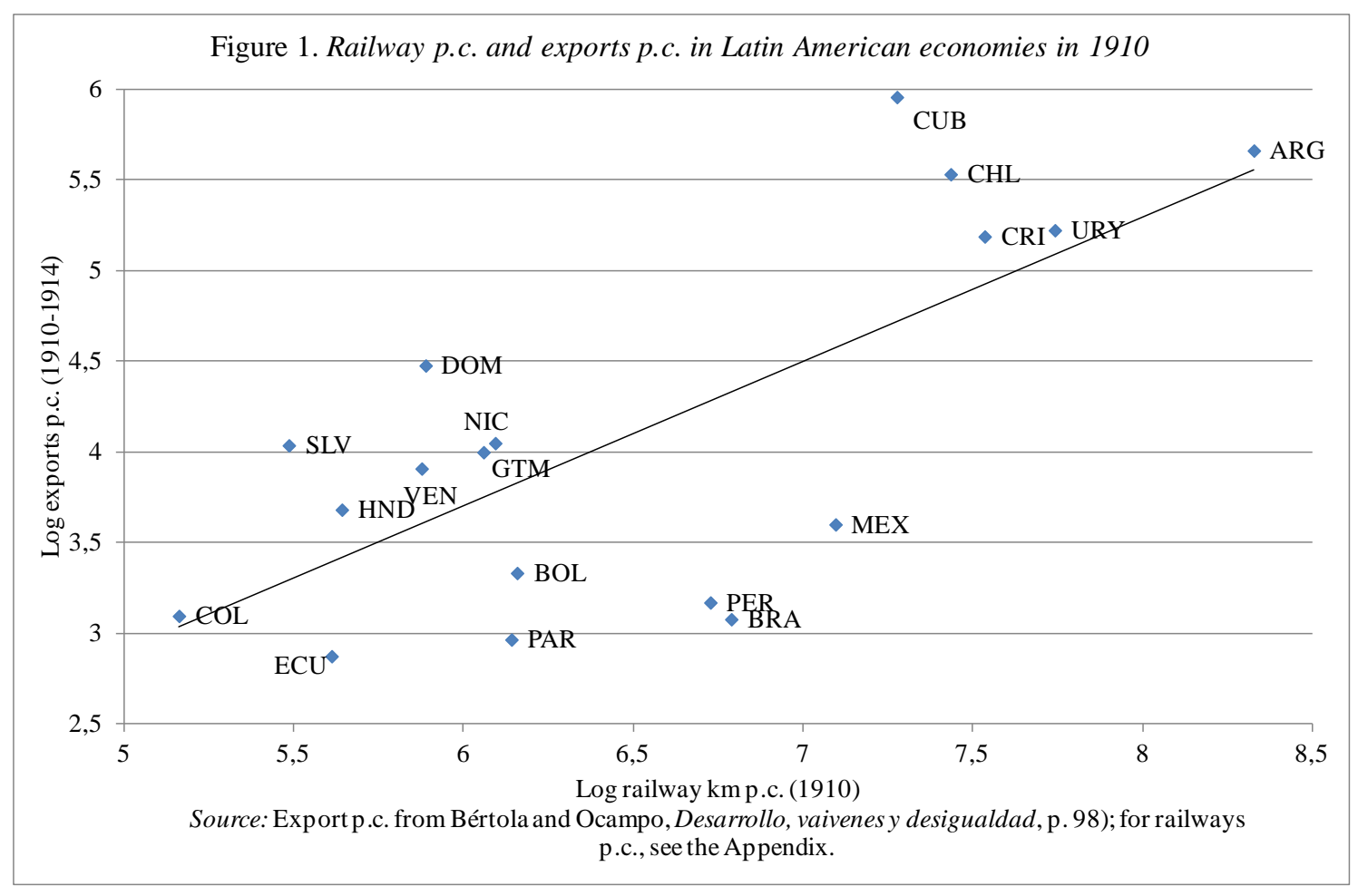


Figure 2. Estimated linear relation between government revenues and railways

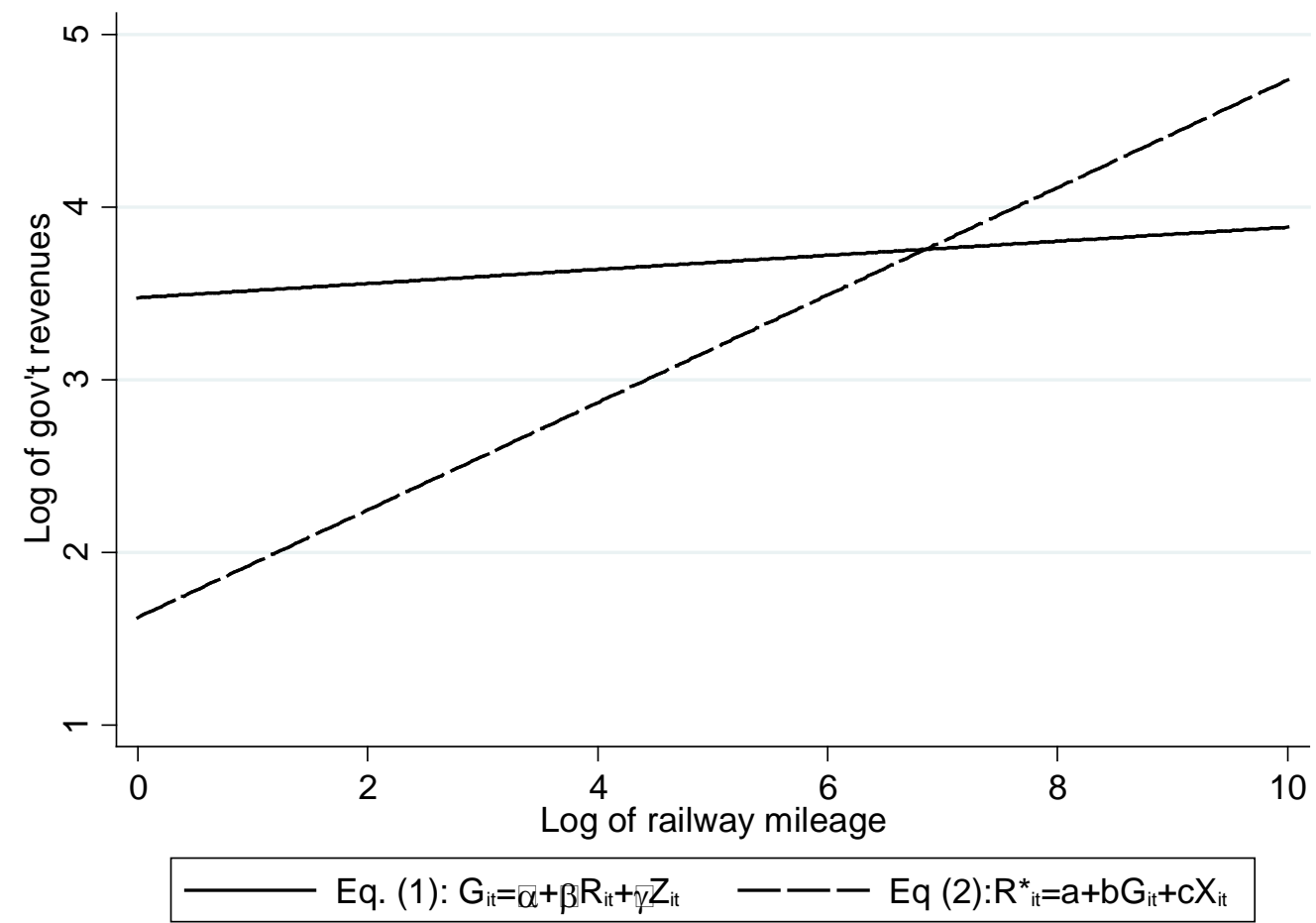

Note: the Figure represents the model with country fixed effects. Whereas the slope $b=3.2$ is obtained directly from Table 4 , for $\beta$ we multiplied the estimate of the elasticity of government revenues to trade from Table $3(0.337)$ by the estimated coefficient of railways in the first stage. The system is stable because this estimate for $\beta=0.04$ is smaller than $b$. Likewise, in the model with country and year fixed effects, $b=2.0$ and $\beta=0.1$. 
Figure 3. Coefficients and 90\% confidence intervals of Log government revenues

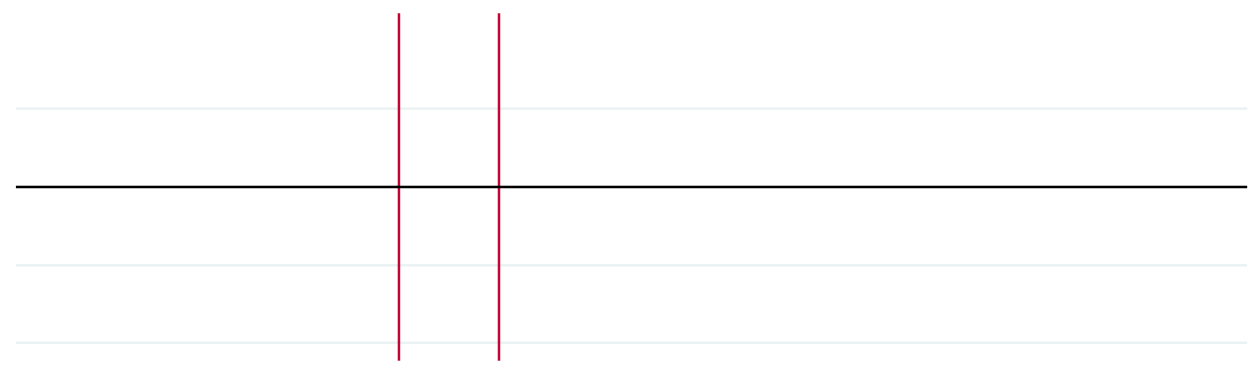

Note: for each observation, the year indicates the end of the sample. 
Figure 4. Actual vs. predicted mileage of the Latin American railway networks (in logs)
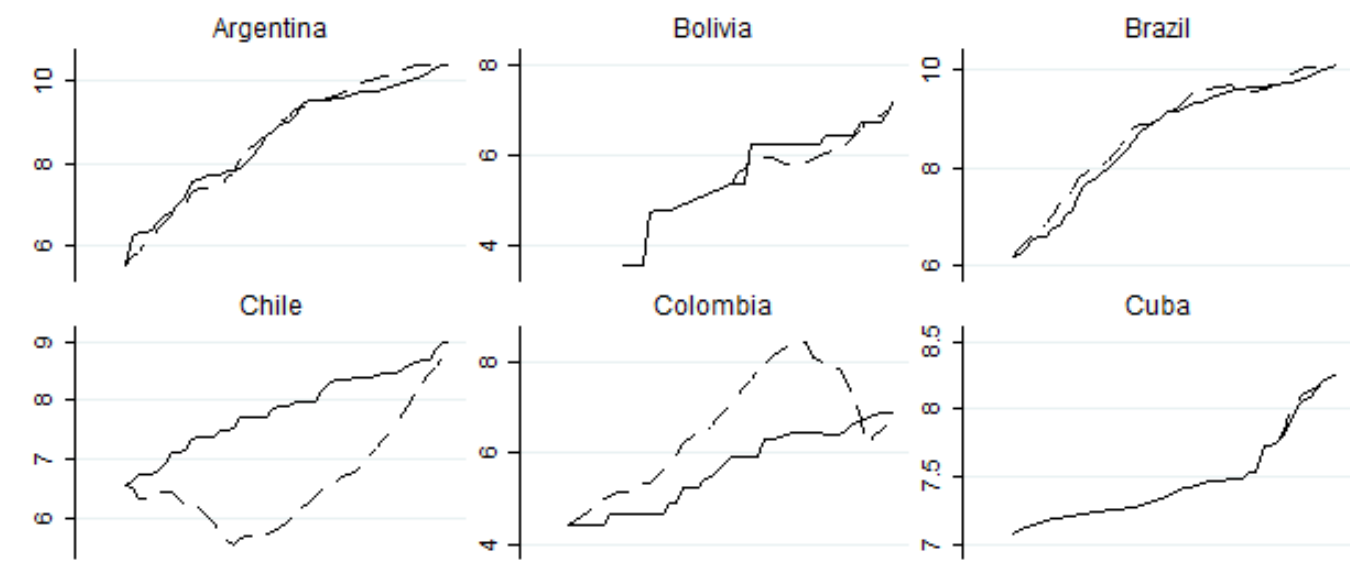

Cuba
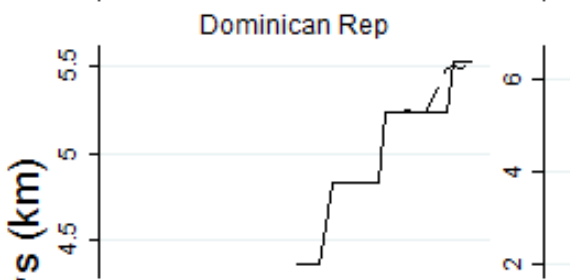

Ecuador
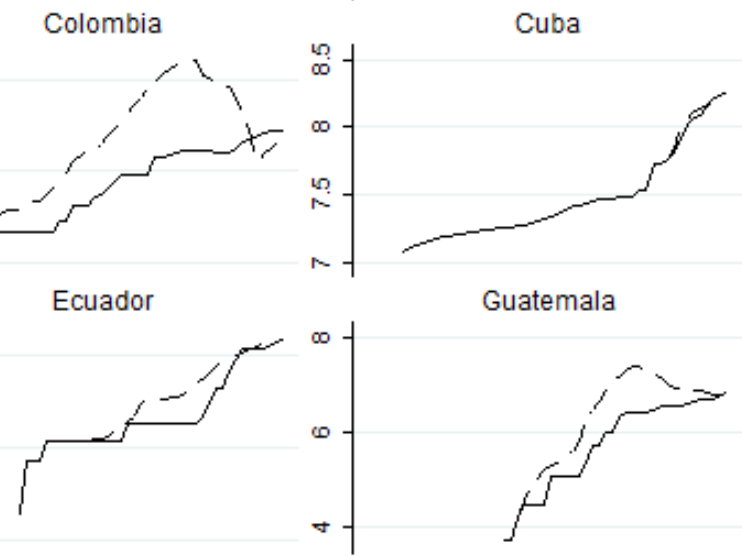

Guatemala

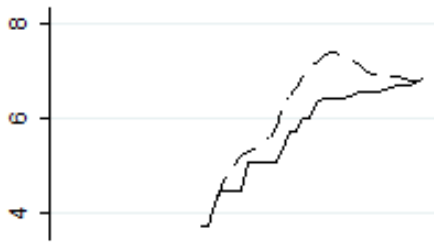

Honduras

Mexico

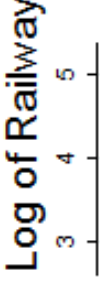

-f
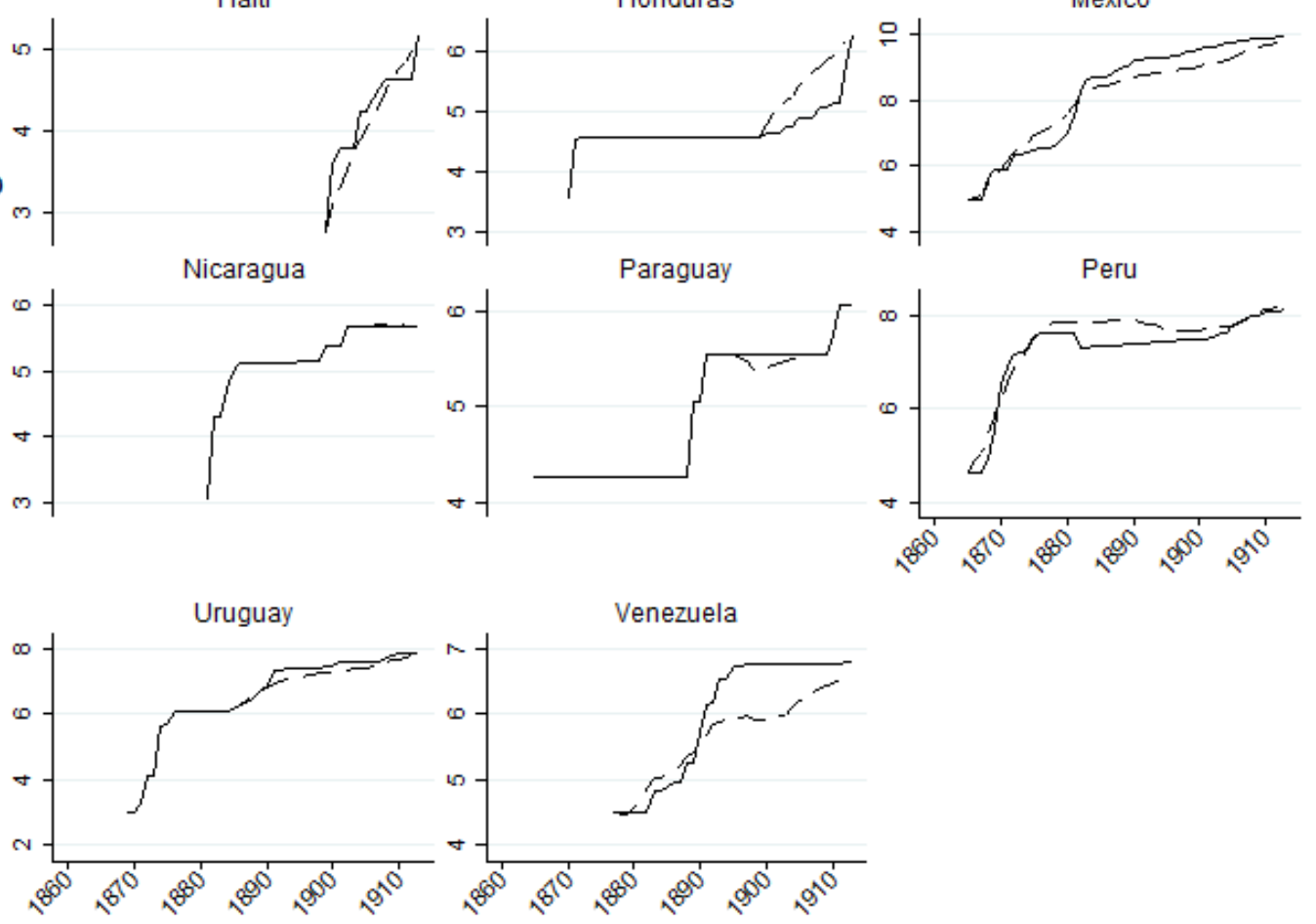

\section{Historical railways $\quad-----$ Predicted railways}

Table 1. Railway mileage in Latin America in 1913 


\begin{tabular}{|c|c|c|c|c|c|}
\hline & $\begin{array}{l}\text { Total length } \\
(\mathrm{km})\end{array}$ & & $\begin{array}{c}\text { Km per } 10,000 \\
k^{2}\end{array}$ & & $\begin{array}{c}\text { Km per } \\
1,000 \text { pop. }\end{array}$ \\
\hline Argentina & 32,494 & Puerto Rico & 672.23 & "Argentina & 4.27 \\
\hline Brazil & 24,614 & Cuba & 339.94 & Chile & 2.19 \\
\hline Mexico & 20,447 & Uruguay & 138.14 & Uruguay & 2.19 \\
\hline Chile & 8,070 & Costa Rica & 134.36 & Costa Rica & 1.77 \\
\hline Cuba & 3,874 & Salvador & 120.66 & Cuba & 1.47 \\
\hline Peru & 3,317 & Argentina & 114.89 & Mexico & 1.27 \\
\hline Uruguay & 2,576 & Chile & 109.71 & Brazil & 0.94 \\
\hline Bolivia & 1,346 & Mexico & 103.74 & Honduras & 0.84 \\
\hline Colombia & 965 & Guatemala & 85.13 & Peru & 0.83 \\
\hline Venezuela & 890 & Haiti & 63.18 & Bolivia & 0.67 \\
\hline Guatemala & 926 & Dominican R. & 51.21 & Paraguay & 0.61 \\
\hline Costa Rica & 696 & Honduras & 47.77 & Panama & 0.57 \\
\hline Puerto Rico & 612 & Brazil & 28.92 & Puerto Rico & 0.52 \\
\hline Ecuador & 606 & Panama & 28.89 & Guatemala & 0.46 \\
\hline Honduras & 532 & Paraguay & 26.96 & Nicaragua & 0.42 \\
\hline Paraguay & 433 & Peru & 23.37 & Venezuela & 0.36 \\
\hline Nicaragua & 294 & Nicaragua & 22.70 & Ecuador & 0.33 \\
\hline Dominican R. & 252 & Ecuador & 21.27 & Dominican R. & 0.32 \\
\hline El Salvador & 250 & Bolivia & 10.41 & Salvador & 0.22 \\
\hline Panama & 217 & Venezuela & 9.76 & Colombia & 0.17 \\
\hline Haiti & 180 & Colombia & 9.41 & Haiti & 0.10 \\
\hline Total & 103,591 & Weighted avg. & 51.76 & Weighted avg. & 1.26 \\
\hline
\end{tabular}

Source: See the Appendix.

Table 2. Summary statistics of variables included in the model

\begin{tabular}{llllll}
\hline Variable & Obs & Mean & Std. Dev. & Min & Max \\
\hline \hline Imports & 513 & -0.540 & 2.530 & -13.564 & 5.412 \\
Railways mileage & 513 & 6.858 & 1.648 & 2.773 & 10.357 \\
Pop×Pop trading partners & 513 & 39.012 & 2.179 & 33.811 & 44.219 \\
Effect. distance to UK & 513 & 1.411 & 0.396 & 0.556 & 2.462 \\
Effect. distance to US & 513 & 0.728 & 0.626 & -0.617 & 1.927 \\
Population & 513 & 7.792 & 1.100 & 5.321 & 10.144 \\
No. of exec. changes & 513 & 0.347 & 0.597 & 0.000 & 3.000 \\
Interstate wars & 513 & 0.055 & 0.227 & 0.000 & 1.000 \\
Other Wars & 513 & 0.066 & 0.249 & 0.000 & 1.000 \\
Gov't Revenues & 479 & 0.797 & 1.292 & -4.023 & 3.724 \\
Ambassadors & 479 & 3.263 & 0.658 & 0.693 & 4.454 \\
Legis. Effectiveness & 479 & 1.762 & 0.777 & 0.000 & 3.000 \\
Terms of Trade & 479 & 4.736 & 0.235 & 4.223 & 5.406 \\
Years since last default & 479 & 0.655 & 0.402 & 0.000 & 1.000 \\
British consol yields & 479 & 1.043 & 0.107 & 0.815 & 1.227 \\
Off Gold & 479 & 0.701 & 0.458 & 0.000 & 1.000 \\
\hline
\end{tabular}

Source: see the Appendix. 
Table 3. The determinants of government revenues in the Latin American countries (1865-1913)

\begin{tabular}{|c|c|c|c|c|c|}
\hline & (1) & (2) & (3) & (4) & (5) \\
\hline \multicolumn{6}{|c|}{ "Second Stage } \\
\hline Log imports (t-1) & $\begin{array}{c}0.516^{* * *} \\
(0.013)\end{array}$ & $\begin{array}{c}0.564 * * * \\
(0.033)\end{array}$ & $\begin{array}{c}0.513^{* * *} \\
(0.027)\end{array}$ & $\begin{array}{c}0.337 * * * \\
(0.082)\end{array}$ & $\begin{array}{c}0.292 * * * \\
(0.079)\end{array}$ \\
\hline Log population (t-1) & & $\begin{array}{c}-0.165^{* * *} \\
(0.061)\end{array}$ & $\begin{array}{c}-0.070 \\
(0.049)\end{array}$ & $\begin{array}{c}0.445 \\
(0.282)\end{array}$ & $\begin{array}{c}1.391^{* * *} \\
(0.345)\end{array}$ \\
\hline No. of exec. Changes (t-1) & & $\begin{array}{c}-0.215^{* * *} \\
(0.077)\end{array}$ & $\begin{array}{c}-0.243^{* * *} \\
(0.073)\end{array}$ & $\begin{array}{c}0.065 \\
(0.040)\end{array}$ & $\begin{array}{c}0.048 \\
(0.042)\end{array}$ \\
\hline Interstate wars (t-1) & & $\begin{array}{c}0.182 \\
(0.129)\end{array}$ & $\begin{array}{c}0.521^{* * *} \\
(0.192)\end{array}$ & $\begin{array}{c}0.007 \\
(0.097)\end{array}$ & $\begin{array}{l}0.221^{*} \\
(0.124)\end{array}$ \\
\hline Other wars (t-1) & & $\begin{array}{c}-0.137 \\
(0.157)\end{array}$ & $\begin{array}{c}-0.184 \\
(0.149)\end{array}$ & $\begin{array}{c}-0.101 \\
(0.083)\end{array}$ & $\begin{array}{l}-0.075 \\
(0.086)\end{array}$ \\
\hline Year FE & No & No & Yes & No & Yes \\
\hline Country FE & No & No & No & Yes & Yes \\
\hline Observations & 513 & 513 & 513 & 513 & 513 \\
\hline \multicolumn{6}{|c|}{ First Stage } \\
\hline Mass & $\begin{array}{c}0.470 * * * \\
(0.036)\end{array}$ & $\begin{array}{c}-1.940 * * * \\
(0.321)\end{array}$ & & $\begin{array}{c}0.691 * * \\
(0.317)\end{array}$ & \\
\hline Distance to UK & $\begin{array}{c}0.038 \\
(0.361)\end{array}$ & $\begin{array}{c}-0.036 \\
(0.323)\end{array}$ & $\begin{array}{c}-0.432 \\
(0.299)\end{array}$ & $\begin{array}{c}0.770 \\
(1.552)\end{array}$ & $\begin{array}{c}1.095 \\
(2.751)\end{array}$ \\
\hline Distance to US & $\begin{array}{c}0.211 \\
(0.279)\end{array}$ & $\begin{array}{c}-0.695^{* *} \\
(0.341)\end{array}$ & $\begin{array}{c}-0.836^{* * *} \\
(0.318)\end{array}$ & $\begin{array}{c}0.391 \\
(1.533)\end{array}$ & \\
\hline Rail length & $\begin{array}{c}-1.042^{* * *} \\
(0.272)\end{array}$ & $\begin{array}{c}-1.029 * * * \\
(0.256)\end{array}$ & $\begin{array}{c}-1.135^{* * *} \\
(0.243)\end{array}$ & $\begin{array}{c}-1.051^{* * *} \\
(0.206)\end{array}$ & $\begin{array}{c}-1.100 * * * \\
(0.187)\end{array}$ \\
\hline Rail length ${ }^{2}$ & $\begin{array}{c}0.119 * * * \\
(0.020)\end{array}$ & $\begin{array}{c}0.143^{* * *} \\
(0.020)\end{array}$ & $\begin{array}{c}0.159 * * * \\
(0.019)\end{array}$ & $\begin{array}{c}0.086^{* * *} \\
(0.015)\end{array}$ & $\begin{array}{c}0.107 * * * \\
(0.014)\end{array}$ \\
\hline F stat $\left(1^{\text {st }}\right.$ stage $)$ & 358.3 & 73.36 & 108.24 & 11.03 & 18.25 \\
\hline Exogeneity $p$-value & 0.000 & 0.000 & 0.000 & 0.127 & 0.138 \\
\hline Over-id p-value & 0.000 & 0.000 & 0.000 & 0.010 & 0.483 \\
\hline Under-id p-value & 0.000 & 0.000 & 0.000 & 0.000 & 0.000 \\
\hline Anderson-Rubin p-value & 0.000 & 0.000 & 0.000 & 0.000 & 0.002 \\
\hline Stock-Wright $p$-value & 0.000 & & & 0.000 & 0.002 \\
\hline
\end{tabular}


Table 4. The determinants of railway development in the Latin American countries (1865-1913)

\begin{tabular}{|c|c|c|c|c|c|c|c|}
\hline & (1) & (2) & (3) & (4) & (5) & (6) & (7) \\
\hline \multicolumn{8}{|c|}{ Second stage } \\
\hline Log gov’t revenues (t-1) & $\begin{array}{c}0.112 * * * \\
(0.033)\end{array}$ & $\begin{array}{l}0.109 * \\
(0.057)\end{array}$ & $\begin{array}{c}0.131^{* *} \\
(0.055)\end{array}$ & $\begin{array}{c}0.090 \\
(0.059)\end{array}$ & $\begin{array}{c}0.143^{* *} \\
(0.062)\end{array}$ & $\begin{array}{c}0.305 * * \\
(0.119)\end{array}$ & $\begin{array}{c}0.181 * * * \\
(0.064)\end{array}$ \\
\hline Log railway mileage (t-1) & $\begin{array}{c}-0.080 * * * \\
(0.021)\end{array}$ & $\begin{array}{c}-0.068 * * * \\
(0.026)\end{array}$ & $\begin{array}{c}-0.091^{* * *} \\
(0.032)\end{array}$ & $\begin{array}{c}-0.059 * * \\
(0.025)\end{array}$ & $\begin{array}{c}-0.083^{* * *} \\
(0.030)\end{array}$ & $\begin{array}{c}-0.095 * * * \\
(0.025)\end{array}$ & $\begin{array}{c}-0.092 * * * \\
(0.023)\end{array}$ \\
\hline Log terms of trade (t-1) & $\begin{array}{c}0.033 \\
(0.044)\end{array}$ & $\begin{array}{c}0.050 \\
(0.053)\end{array}$ & $\begin{array}{c}-0.006 \\
(0.065)\end{array}$ & $\begin{array}{c}0.050 \\
(0.066)\end{array}$ & $\begin{array}{c}0.018 \\
(0.068)\end{array}$ & $\begin{array}{c}-0.149 \\
(0.121)\end{array}$ & $\begin{array}{c}-0.038 \\
(0.077)\end{array}$ \\
\hline Log pop×pop trad partners $(\mathrm{t}-1)$ & & $\begin{array}{c}-0.011 \\
(0.011)\end{array}$ & & $\begin{array}{c}-0.009 \\
(0.012)\end{array}$ & $\begin{array}{c}-0.017 \\
(0.010)\end{array}$ & $\begin{array}{l}-0.091 * \\
(0.051)\end{array}$ & $\begin{array}{c}-0.233 * * * \\
(0.083)\end{array}$ \\
\hline Log effect distance to UK (t-1) & & $\begin{array}{c}0.007 \\
(0.022)\end{array}$ & & $\begin{array}{c}0.004 \\
(0.021)\end{array}$ & $\begin{array}{c}0.017 \\
(0.026)\end{array}$ & $\begin{array}{c}-0.087 \\
(0.399)\end{array}$ & $\begin{array}{c}-1.104^{* *} \\
(0.509)\end{array}$ \\
\hline Log effect distance to US (t-1) & & $\begin{array}{c}-0.023 \\
(0.028)\end{array}$ & & $\begin{array}{l}-0.010 \\
(0.026)\end{array}$ & $\begin{array}{c}-0.012 \\
(0.018)\end{array}$ & $\begin{array}{c}-0.078 \\
(0.396)\end{array}$ & $\begin{array}{l}1.205^{* *} \\
(0.542)\end{array}$ \\
\hline No. of exec. changes (t-1) & & & $\begin{array}{c}0.002 \\
(0.011)\end{array}$ & $\begin{array}{c}-0.001 \\
(0.012)\end{array}$ & $\begin{array}{c}0.008 \\
(0.014)\end{array}$ & $\begin{array}{l}-0.019 \\
(0.021)\end{array}$ & $\begin{array}{c}-0.004 \\
(0.016)\end{array}$ \\
\hline Interstate wars (t-1) & & & $\begin{array}{c}-0.051 \\
(0.041)\end{array}$ & $\begin{array}{c}-0.030 \\
(0.034)\end{array}$ & $\begin{array}{c}-0.060 * \\
(0.034)\end{array}$ & $\begin{array}{c}-0.016 \\
(0.049)\end{array}$ & $\begin{array}{c}-0.102^{* *} \\
(0.042)\end{array}$ \\
\hline Other wars (t-1) & & & $\begin{array}{c}0.013 \\
(0.023)\end{array}$ & $\begin{array}{c}0.014 \\
(0.024)\end{array}$ & $\begin{array}{c}0.031 \\
(0.026)\end{array}$ & $\begin{array}{c}0.062 \\
(0.042)\end{array}$ & $\begin{array}{c}0.006 \\
(0.029)\end{array}$ \\
\hline Years since last default & & & $\begin{array}{c}-0.015 \\
(0.027)\end{array}$ & $\begin{array}{c}0.000 \\
(0.023)\end{array}$ & $\begin{array}{c}-0.018 \\
(0.024)\end{array}$ & $\begin{array}{c}-0.014 \\
(0.032)\end{array}$ & $\begin{array}{c}-0.014 \\
(0.026)\end{array}$ \\
\hline British consol yields & & & $\begin{array}{c}-0.159 \\
(0.153)\end{array}$ & $\begin{array}{l}-0.035 \\
(0.125)\end{array}$ & $\begin{array}{c}0.317 \\
(1.602)\end{array}$ & $\begin{array}{c}-0.226 \\
(0.143)\end{array}$ & \\
\hline Off gold & & & $\begin{array}{l}0.026 * \\
(0.016)\end{array}$ & $\begin{array}{c}0.022 \\
(0.030)\end{array}$ & $\begin{array}{c}0.058 \\
(0.039)\end{array}$ & $\begin{array}{c}0.068 \\
(0.050)\end{array}$ & $\begin{array}{c}0.048 \\
(0.038)\end{array}$ \\
\hline Year FE & No & No & No & No & Yes & No & Yes \\
\hline Country FE & No & No & No & No & No & Yes & Yes \\
\hline Observations & 479 & 479 & 479 & 479 & 479 & 479 & 479 \\
\hline \multicolumn{8}{|c|}{ First stage } \\
\hline Diplomatic representation & $\begin{array}{c}-0.001 \\
(0.082)\end{array}$ & $\begin{array}{c}-0.106 \\
(0.067)\end{array}$ & $\begin{array}{c}-0.062 \\
(0.044)\end{array}$ & $\begin{array}{c}-0.167 * * * \\
(0.062)\end{array}$ & $\begin{array}{l}0.0477 \\
(0.061)\end{array}$ & $\begin{array}{c}0.231 * * * \\
(0.070)\end{array}$ & $\begin{array}{c}0.341^{* * *} \\
(0.068)\end{array}$ \\
\hline Legislative effectiveness & $\begin{array}{c}0.256 * * * \\
(0.048)\end{array}$ & $\begin{array}{c}0.201^{* * *} \\
(0.058)\end{array}$ & $\begin{array}{c}-0.169 * * * \\
(0.044)\end{array}$ & $\begin{array}{c}0.173^{* * *} \\
(0.054)\end{array}$ & $\begin{array}{c}0.187 * * * \\
(0.052)\end{array}$ & $\begin{array}{c}-0.007 \\
(0.060)\end{array}$ & $\begin{array}{l}0.103 * \\
(0.061)\end{array}$ \\
\hline F stat (1st stage) & 15.65 & 6.500 & 7.650 & 7.240 & 7.390 & 5.55 & 13.26 \\
\hline Exogeneity $p$-value & 0.025 & 0.124 & 0.055 & 0.233 & 0.025 & 0.000 & 0.003 \\
\hline Over-id p-value & 0.502 & 0.219 & 0.246 & 0.093 & 0.504 & 0.805 & 0.307 \\
\hline Under-id p-value & 0.000 & 0.002 & 0.000 & 0.001 & 0.001 & 0.004 & 0.000 \\
\hline Anderson-Rubin p-value & 0.008 & 0.078 & 0.007 & 0.110 & 0.031 & 0.001 & 0.001 \\
\hline Stock-Wright $p$-value & 0.009 & 0.089 & 0.007 & 0.119 & 0.040 & 0.006 & 0.001 \\
\hline
\end{tabular}

Robust standard errors in parentheses. ${ }^{* * *} \mathrm{p}<0.01,{ }^{*} \mathrm{p}<0.05,{ }^{*} \mathrm{p}<0.1$. Omitted coefficients: constant, border changes and fixed effects. 
Table 5. Elasticity estimates for different estimation methods

\begin{tabular}{ccccccc}
\hline & \multicolumn{3}{c}{ Partial adjustment } & 3SLS & Arellano & Cointegrated panel \\
& 1 year & 2 years & 3 years & & Bond & $($ PMG) \\
\hline \hline$\varepsilon\left(\mathrm{R}^{*}, \mathrm{G}\right)$ & $1.967 * * *$ & $1.749^{* * *}$ & $1.764^{* * *}$ & -1.681 & 0.052 & $1.072^{* * *}$ \\
& $(0.543)$ & $(0.428)$ & $(0.413)$ & $(7.390)$ & $(0.134)$ & $(0.134)$
\end{tabular}

*** $\mathrm{p}<0.01,{ }^{* *} \mathrm{p}<0.05, * \mathrm{p}<0.1$. Standard errors in parentheses computed from the so-called Delta method, when applicable.

Table 6. Counterfactuals for government revenues

\begin{tabular}{cccccc}
\hline Counterfactual & $\mathrm{R}_{0,1913}$ & $\mathrm{R}_{1,1913}$ & $\begin{array}{c}\text { Permanent } \\
\%\end{array}$ & $\begin{array}{c}\text { Once } \\
\%\end{array}$ & $£^{\prime} 000$ \\
\hline \hline COL $\Rightarrow$ ARG & 0.94 & 11.49 & 2.96 & 107.80 & 1522.1 \\
COL $\Rightarrow$ URY & 0.94 & 13.81 & 3.10 & 113.26 & 1651.2 \\
PER $\Rightarrow$ MEX & 2.34 & 10.37 & 1.42 & 51.61 & 1819.3 \\
HND $\Rightarrow$ CRI & 4.78 & 13.44 & 1.03 & 37.52 & 455.3 \\
\hline
\end{tabular}

$\mathrm{R}_{0,1913}\left(\mathrm{R}_{1,1913}\right)$ stands for the actual (counterfactual) railway density in 1913, expressed in km per $1,000 \mathrm{~km}^{2}$. 